\title{
Evaluation of an integrated sewage pipe with ground heat exchanger for long-term efficiency estimation
}

\author{
By \\ Connor Mitchell Dacquay
}

\begin{abstract}
A thesis submitted to
the Faculty of Graduate Studies

in partial fulfilment of

the requirements for the degree of

Master of Science

Department of Civil Engineering

Faculty of Engineering

University of Manitoba

Winnipeg, Manitoba
\end{abstract}

February 2020

(C) Copyright

2020, Connor Mitchell Dacquay 


\section{Abstract}

Extracting heat from a sewage pipe through a typical horizontal ground heat exchanger has recently been introduced as a renewable energy alternative to reduce fossil fuel usage. This paper presents a novel design for a ground heat exchanger that extracts heat from the sur-

rounding soil and sewage within the pipe while simultaneously being carried to a wastewater treatment plant. This research focuses on the long-term efficiency of the system under transient conditions in a cold climate. A numerical model using COMSOL Multiphysics was developed to verify the sustainability of the system for over 25 years. The model used constant inlet fluid temperatures to evaluate heat by conductive and convective heat transfer mechanisms within the pipe and surrounding soils by considering phase change of pore water. The results showed, by adopting the operation strategy proposed in this study, a maximum temperature change in the surrounding soil adjacent to the heat extraction system over 25 years was $0.10^{\circ} \mathrm{C}$ during the heating season in Winnipeg, Manitoba. The horizontal distance at which the heat extraction system did not show an impact on temperature change of adjacent soil was determined at 4 meters. Critical parameters in this evaluation were system depth, sewage level, and the high-density polyethylene pipe thermal properties. The sustainability of the system was not affected by the system depth due to thermal balancing between climatic, subsurface and sewage heat fluxes. Sustainable behavior was achieved at $50 \%$ and $75 \%$ of sewage pipe capacity. The effect on thermal performance from the high-density polyethylene pipe thermal properties was deemed insignificant. 


\section{Acknowledgments}

I would like to express my deepest gratitude to my advisor Dr. Hartmut Holländer for his full support, expert guidance, understanding and encouragement throughout my study and research. In addition, I would like to express my appreciation to my co-supervisors: Dr. Miroslava Kavgic, and advisory committee members: Dr. Pooneh Maghoul (internal), Dr. Scott Ormiston (external). Their thoughtful questions and comments were valued greatly.

Finally, I would like to thank the Natural Sciences and Engineering Research Council of Canada (NSERC) via the grant ENG 515318-17 and also Lafarge Canada Inc. for providing data on the @ Source-Energy pipe. 


\section{Contributions of Authors}

Connor Dacquay, Hartmut M. Holländer, Miroslava Kavgic, Pooneh Maghoul, Hongwei Liu, Hikari Fujii. Evaluation of an integrated sewage pipe with ground heat exchanger for long-term efficiency estimation.

a) Connor Dacquay: Developed the COMSOL Multiphysics model and performed data analysis and was the main writer of the paper.

b) Hartmut M. Holländer: Suggested and supervised this research, data analysis, and assisted with the writing and editing of the paper.

c) Miroslava Kavgic: Assisted with the writing and editing of the paper.

d) Pooneh Maghoul: Assisted with the writing and editing of the paper.

e) Hongwei Liu: Assisted in the modeling process and with the writing and editing of the paper.

f) Hikari Fujii: Assisted in the model validation process and with the writing and editing of the paper. 


\section{Table of Contents}

1 Chapter 1-Introduction $\quad 7$

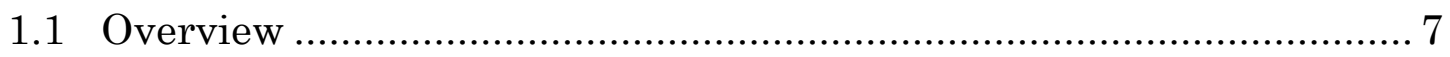

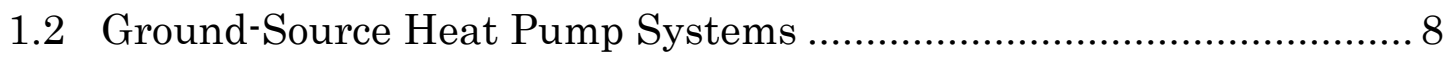

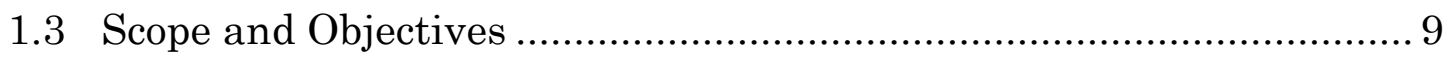

2 Chapter 2-Literature Review $\quad 11$

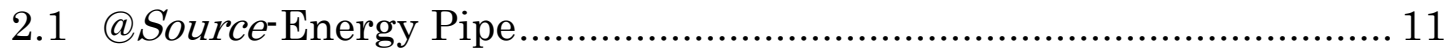

2.2 Ground Heat Exchangers .............................................................. 11

2.3 Heat Extraction from Wastewater ................................................... 13

2.4 Sustainable Energy Balancing........................................................ 14

3 Chapter 3 - Evaluation of an Integrated Sewage Pipe with Ground Heat $\begin{array}{ll}\text { Exchanger for Long-Term Efficiency Estimation } & 17\end{array}$

3.1 Numerical model description ......................................................... 17

3.1.1 Numerical simulation method............................................... 17

3.1.2 Governing Equations ............................................................ 23

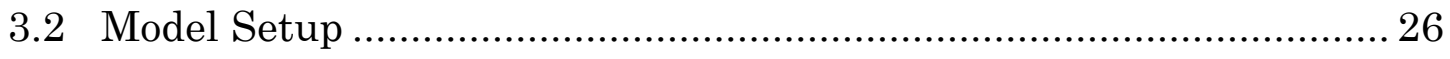

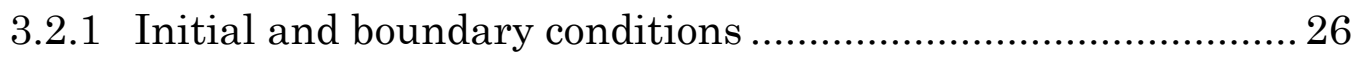

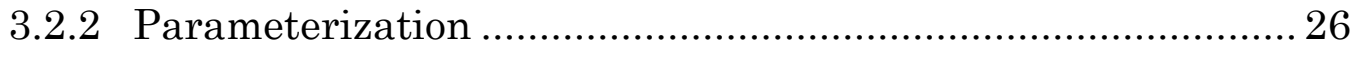

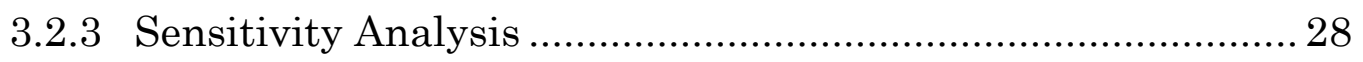

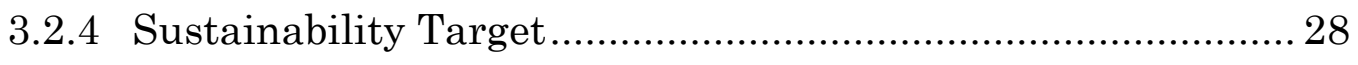

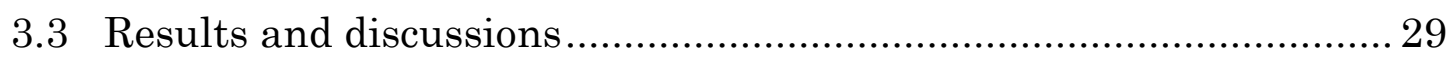

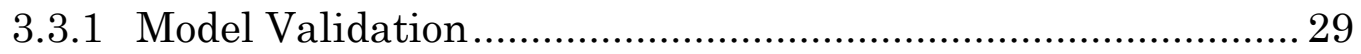

3.3.2 Long-term sustainability implications ...................................... 31

3.3.3 Heating season................................................................... 34

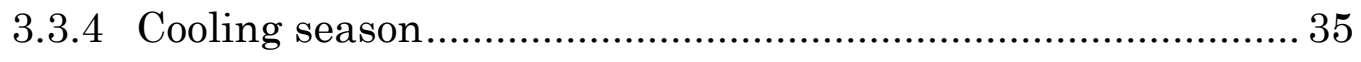




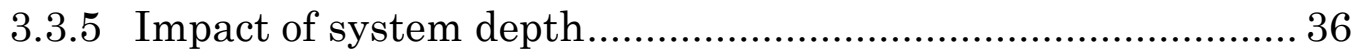

3.3.6 Impact of HDPE thermal properties ....................................... 39

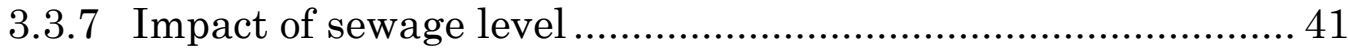

3.3.8 Theoretical $\mathrm{CO}_{2}$ emission and cost savings ........................... 44

4 Chapter 4-Conclusion and Recommendation for Future Work 47

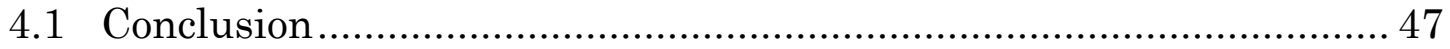

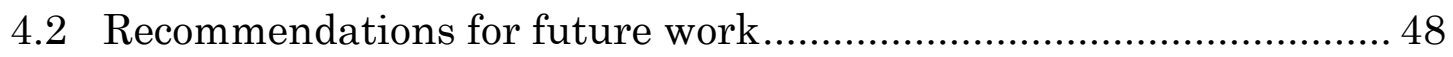

5 Bibliography $\quad 50$ 


\section{List of Tables}

Table 1: Monthly loads from the natural gas (NG) furnace and AC unit of a typical middleclass Canadian Prairie home (Manitoba Hydro, 2019b). 22

Table 2: Thermal properties of model materials (Bergman et al., 2007; Hafeez \& Abdalla, 1972; Melinder, 2007; Zhu \& Michalowski, 2005).

Table 3: Correlation coefficients for sensitivity analysis on clay thermal properties $\pm 50 \%$ against original properties. 28

Table 4: Comparison of reported City of Winnipeg and simulated frost depth (City of Winnipeg, 2017, 2018). 30

Table 5: Corresponding $\Delta \mathrm{T}_{\max }$ and ATC with distance from heat extraction system over 25 years. 32

Table 6: Corresponding $\Delta \mathrm{T}_{\max }$ and ATC with distance from heat extraction system over 5 years at depths of $4,5,6,7$, and $8 \mathrm{~m}$ 37

Table 7: Corresponding $\Delta \mathrm{T}_{\max }$ and ATC with distance from heat extraction system over 5 years with $50 \%$ and $75 \%$ sewage level. 43

Table 8: Required monthly work input for heat pump to meet energy demand. 44

Table 9: Annual operating costs and savings for a 25-year period based on a $10 \mathrm{~m}$ length of pipe. 46

Table 10: @ Source-Energy pipe system capital costs for the base case. 46 


\section{List of Figures}

Figure 1: 3D, front and side schematic of numerical domain...................................... 19

Figure 2: Soil temperatures adjacent to the system at $3 \mathrm{~m}$ depth. ................................. 32

Figure 3: Soil temperatures at $0.1 \mathrm{~m}$ adjacent to the system at $3 \mathrm{~m}$ depth for various

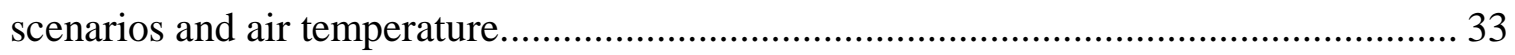

Figure 4: Soil temperatures at $1.0 \mathrm{~m}$ below the system for various scenarios and air

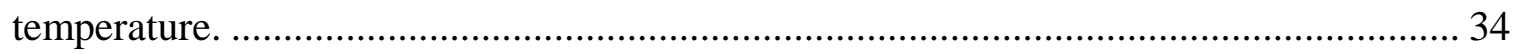

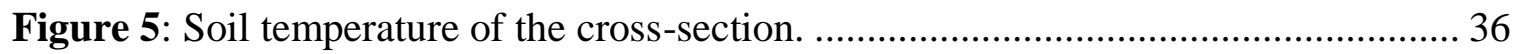

Figure 6: Difference between scenario-specific soil temperatures at $0.1 \mathrm{~m}$ from the system

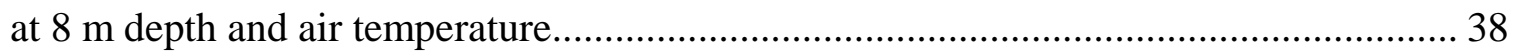

Figure 7: Difference between heat extraction system implementation with and without

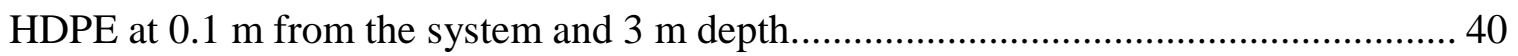

Figure 8: Difference between scenario-specific soil temperatures at $0.1 \mathrm{~m}$ from system at $3 \mathrm{~m}$ depth and air temperature with $75 \%$ sewage pipe capacity.................................. 42 


\section{Chapter 1 - Introduction}

\subsection{Overview}

Natural gas and electricity together accounted for $82.5 \%$ of all residential energy use in 2013 (Natural Resources Canada, 2013a). The average annual Manitoban household consumed 105.4 GJ of energy in 2011 which is identical to the Canadian average (Natural Resources Canada, 2013b). Nearly half of the average household consumption was natural gas, which is mainly used for heating. Due to an increasing energy demand from population increase, Canada has been pressured to provide solutions to reduce greenhouse gas (GHG) emissions (National Energy Board, 2017). In 2013, Canada’s total GHG emissions were

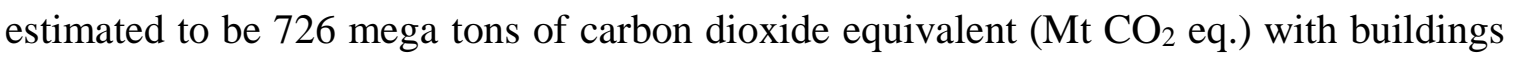
contributing 12\% (Government of Canada, 2015). Canada pledged an economy-wide target to reduce GHG emissions in May 2015 by 30\% below 2005 levels by 2030 as outlined in the Paris Agreement. Currently, Canada is projected to significantly miss its 2020 and 2030 climate target with the set of measures it currently has in place. The projected target for 2020 is $622 \mathrm{Mt} \mathrm{CO}_{2}$ eq. and the projected outcome is $675 \mathrm{Mt} \mathrm{CO}_{2}$ eq. As for 2030, the projected target is $524 \mathrm{Mt} \mathrm{CO}_{2}$ eq. and the projected outcome is $592 \mathrm{Mt} \mathrm{CO}_{2}$ eq. Canada 
must apply an action plan for implementing new renewable technologies if it is going to meet its 2020 target and be in a position to meet the 2030 target.

A new technology, the @ Source-Energy pipe, has been developed by the Renewable Resource Recovery Corporation for an extreme climate that combines a typical horizontal ground heat exchanger (GHE) with a sewage pipe. The @ Source-Energy pipe is a hollow concrete cylinder with a helical high-density polyethylene (HDPE) pipe embedded within the pipe walls. Heat is captured from effluent in sanitary and storm sewer pipes, and from adjacent ground. The @ Source-Energy pipe has the capability to replace natural gas furnaces and air conditioning (AC) units in residential homes which would reduce Canada's total GHG emissions. Due to the novelty of the technology, a performance analysis in an extreme climate has not been performed yet. As one of the world's top ten GHG emitters, Canada's emissions reductions pathway is important for shifting the world to a low-carbon pathway that avoids severe impacts of climate change. This thesis presents the recommendations for implementing the @ Source-Energy pipe and the predictive impacts if implemented.

\subsection{Ground-Source Heat Pump Systems}

The GHE is the most important part of the ground-source heat pump (GSHP) system. In conventional GSHP systems, the pipes of GHEs can be positioned vertically or horizontally. The advantages of horizontal heat exchangers, as compared to heat exchangers with vertical pipes, include lower investment cost and the possibility to make use of ambient energy in order to compensate for ground heat deficit (Neupauer, Pater, \& Kupiec, 2018). 
Recently, GSHPs have been extensively used for heating and cooling of buildings. It is estimated that GSHP system installations have grown continuously on a global basis with the range from $10 \%$ to $30 \%$ annually in recent years (Bose, 2002). In Canada, approximately 50,000 residential and 5,000 commercial heat pumps were installed in 2010 (Lund, Freeston, \& Boyd, 2010). Heat pumps transfer heat by circulating a refrigerant through a cycle of evaporation and condensation (Ajah et al., 2008). This process allows for a reduced consumption of energy compared to conventional furnaces. A study based in Wroclaw, Poland recently presented the national carbon reduction scenario of replacing the individual heat sources with electrically driven heat pumps in residential space heating (Elżbieta, 2018). The study concluded that the space heating sector based on electrically run heat pumps may decrease the $\mathrm{CO} 2$ emission up to $42.2 \%$. Although GSHP systems have been researched comprehensively and are increasing in popularity, the combination of a GSHP with a sewage pipe, similar to the @ Source-Energy pipe, is a novel system..

\subsection{Scope and Objectives}

The overall goal of the proposed research is to create predictive models that determine the feasibility of applying the @Source-Energy pipe system to new residential developments. The main objective focuses on estimating the long-term efficiency of the @ SourceEnergy pipe system under transient conditions. This main objective has five sub-objectives:

1) Determine the long-term sustainability implications based on a sustainability target.

2) Determine the adjacent distance at which there is no thermal impact. 
3) Determine the effect of the HDPE thermal properties on the thermal performance of the system.

4) Determine the thermal performance at 4, 5, 6, 7 and $8 \mathrm{~m}$ depths.

5) Determine the effect of differential sewage levels.

This thesis is organized by the following; in chapter 2, a review of ground-source heat pump implementation, ground heat exchangers, wastewater heat extraction, the @ SourceEnergy pipe and sustainable energy balancing is present. Chapter 3 details the performance of the @ Source-Energy pipe in a cold climate (main objective). Lastly, Chapter 4 presents the major conclusions from the study and finalises with recommendations for future work. 


\section{Chapter 2 - Literature Review}

\section{$2.1 @$ Source-Energy Pipe}

The @Source-Energy pipe is a hollow concrete cylinder with a helical HDPE pipe embedded within the pipe walls (Renewable Resource Recovery Corp., 2009: Source-Energy Pipe). The HDPE pipe has an outlet and inlet on each length of pipe which is used to attach to a main supply and return header. The main headers are attached to a heat pump and circulator and used either independently or in tandem with a vertical borehole HDPE piping geothermal ground heat exchanger. The @ Source-Energy pipe system can circulate a heat exchange fluid within the concrete which is controlled by a heat pump in the building. This allows for the transfer of heat into and out of the building to the @Source-Energy pipe system, therefore heating the building in cold weather and cooling the building in hot weather.

\subsection{Ground Heat Exchangers}

In the past two decades, most researchers have focused on the heat transfer performance and optimization of GHEs. A recent study by Kayaci and Demir (2018) examined effects of different parameters on the soil temperature profile and obtained steady periodic soil temperature profiles by numerical modelling of a horizontal GHE with a GSHP. The authors concluded that optimum design parameters are a function of heating load as well as the meteorological conditions but failed to examine the system over a period greater then 
10 years. Gauthier, Lacroix, and Bernier (1997) performed a numerical study for the thermal behaviour of soil heat exchanger-storage systems that was focused on reducing the energy consumption of greenhouses. Energy storage analysis methods for varying depths of buried pipes were concluded but the study did not consider a GSHP connected to the heat exchanger-storage system. A study conducted by $\mathrm{Bi}$, Chen, and $\mathrm{Wu}$ (2002) developed a heat transfer model of an underground heat exchanger coil connected to a GSHP system. The underground temperature distribution of the coil was solved numerically but the study did not include an analysis of a horizontal ground heat exchanger. Dai, Shang, $\mathrm{Li}$, and $\mathrm{Li}$ (2016) established a three-dimensional transient physical and mathematical model of a GHE and the surrounding soil by considering the heat permeability and groundwater seepage. The authors concluded that the thermal interference distance is within a radius of $1 \mathrm{~m}$ but did not analyze the long-term effects of the thermal impact. Michopoulos and Kyriakis (2009) developed a model to predict the fluid temperature at the ground heat exchanger outlet. These researchers considered the heat transfer phenomenon in the soil but did not implement the model in an extreme climate. With dynamic thermal boundary conditions, Wang, Long, and Qin (2013) established a numerical simulation model to predict the solid zone (pipe, grout and soil) temperature variation for a long-term heat storage and a largescale application of the GHE. The study considered transient thermal boundary conditions but did not include varying soil properties based on volumetric water content. These studies are important because they provide a base of knowledge in ground heat exchangers as an energy source for heat pumps. 


\subsection{Heat Extraction from Wastewater}

The use of wastewater heat as a source for heating systems is rarely considered. A study in The Netherlands concluded that heat extraction from wastewater can obtain up to 56 PJ/y based on a 17 M population (Frijns, Hofman, \& Nederlof, 2013). The study used average temperatures of greywater and sewage from households to obtain a theoretical maximum of heat recovery but did not consider the costs to implement heat extraction technology. Another study modeled the annual performance of two different system scenarios by extracting heat from wastewater immediately after use and concluded with an overall coefficient of performance (COP) of above 6 for the systems when used with a heat pump (Meggers \& Leibundgut, 2011). The first scenario supplied up to $4400 \mathrm{kWh}$ of heat for all hot water events, such as showers and dishwashing, with only $790 \mathrm{kWh}$ of electricity consumption from a heat pump. The second scenario regenerated directly the hot water supply just for bathroom fixtures at $2400 \mathrm{kWh}$ with just $410 \mathrm{kWh}$ of energy. Both scenarios failed to consider sewage as a heat source. Peráčková and Podobeková (2013) presented heat recovery systems for low-energy buildings for low temperature heating, high temperature cooling and also to preheat domestic water. This study described a heat exchanger integrated in the concrete wall of a sewage pipe, but did not evaluate the performance of the system. A sewage heat pump system was designed and analyzed in Korea to investigate the feasibility of the wastewater use for a heat pump as a heat source (Baek, 2005). The study forecasted that the yearly mean COP of the heat pump is about 4.8 but failed to analyze the system performance greater than 1 year. It was illustrated in Berlin, Germany that by selecting a suitable combination of heat exchanger and heat pump, about $40 \mathrm{kWh} / \mathrm{h}$ 
average in-house wastewater thermal heat can be recovered and about $230 € / \mathrm{d}$ can be saved (Alnahhal \& Spremberg, 2016). This study showed that wastewater heat can contribute to reduction of energy needed for hot water provision by about $30 \%$ but did not analyze the wastewater heat recovery from a sewage pipe. A key review from the authors Culha, Gunerhan, Biyik, Ekren, and Hepbasli (2015) stated that the utilization of wastewater source heat pump (WWSHP) systems reduce carbon emission, heat emission to environment, air pollution, and electricity consumption but a minimal number of studies on computational fluid dynamics (CFD) analysis of wastewater heat exchangers are available. Chen, Ma, Ji, Lu, and Wang (2017) analyzed a wastewater heat recovery system from discharged slurries while applying a CFD approach. The authors concluded that the system showed great potential to increase net raw biogas production with low equipment investments but failed to apply the system to a residential heating scenario. The proposed feasibility study of the @ Source-Energy pipe for analysis of implementation scenarios will allow for an additional analysis of wastewater heat exchangers using CFD.

\subsection{Sustainable Energy Balancing}

The sustainability of the soil temperature throughout a 25 -year period is necessary because geothermal heat pump systems have an average 20+ year life expectancy (U.S. Department of Energy, 2011). The temperature difference within the soil and effluent compared with the refrigerant will decrease over time due to the constant heat extraction, therefore a long-term efficiency evaluation of the @ Source-Energy pipe is needed. Ground temperature changes that would occur under certain conditions were simulated using a two- 
dimensional transient, groundwater flow-coupled model by Dölçek, Atkins, Harper, Tinjum, and Choi (2017) to determine the sustainability of GHEs. The study concluded that a significant increase in soil temperature surrounding the borehole will occur over a 20-year period but did not investigate a horizontal heat exchanger application. Another study focussed on the interactions between the soil, horizontal heat exchangers, and the aboveground environment (Garcia, Verhoef, Luigi, Main, \& Gan, 2012). It was concluded that the GHE modified heat and water transport in the soil to such a degree that it could affect the GSHP performance but the authors did not analyze the system greater than a 1year period. In the work performed by Hein, Kolditz, Görke, Bucher, and Shao (2016), a comprehensive numerical model was constructed to include flow and heat transport processes to determine the sustainability of a GSHP. The study concluded that there is a potential of reducing the borehole heat exchanger length if sufficient groundwater flow helps the subsurface thermal recovery but did not include phase change seasonal freezing soil. A study performed by Neuberger, Adamovský, and Šedová (2014) tested the temperature changes and heat flow in soils that host "slinky" type horizontal heat exchangers. The "slinky" type heat exchanger is a type of heat exchanger very similar to the @SourceEnergy pipe without the pre-cast concrete. The test concluded that more than three years of validation indicate that the slinky-type horizontal ground heat exchanger can be considered as stable energy source for heat pumps. The temperature difference at the beginning and end of the heating seasons did not exceed $2^{\circ} \mathrm{C}$ in the four years that measurements were taken. The conclusions from this study will be used as a benchmark in the proposed research for the analysis of the sustainability of the @ Source-Energy pipe. 


\section{Chapter 3 - Evaluation of an Integrated Sewage}

\section{Pipe with Ground Heat Exchanger for Long-Term Efficiency Estimation}

\subsection{Numerical model description}

\subsubsection{Numerical simulation method}

In this paper, the finite element solver COMSOL Multiphysics (COMSOL Multiphysics, 2007) was used to investigate conductive heat transfer in soil by considering the effect of pore water phase change coupled with convective heat transfer through pipe flow. A soil block of $15 \mathrm{~m}$ x $15 \mathrm{~m}$ x $12 \mathrm{~m}$ was initially modelled to simulate the natural conditions of ground temperature without heat extraction or heat injection. The following pair of simulations implemented the @ Source-Energy pipe at a $3 \mathrm{~m}$ depth with and without heat extraction to show the effect on soil temperature when the @ Source-Energy pipe was turned on versus off . Furthermore, the @Source-Energy pipe was investigated at buried depths of $4,5,6,7$, and $8 \mathrm{~m}$ to analyze the effect of pipe buried depth on the heat extraction performance. The @Source-Energy pipe was also analyzed with the HDPE thermal properties included versus concrete thermal properties to determine the impact of the material of the HDPE piping. Lastly, the @ Source-Energy pipe was analyzed with 50\% and 75\% sewage pipe capacity levels to determine the change in thermal performance. The analyzed 
@ Source-Energy pipe was $10 \mathrm{~m}$ in length composed of concrete and HDPE. The concrete pipe has an inner diameter of $0.70 \mathrm{~m}$ and an outer diameter of $0.90 \mathrm{~m}$ (Fig. 1). The HDPE pipe was implanted inside the concrete to a depth of $0.05 \mathrm{~m}$ from the inner diameter of the concrete. The HDPE pipe has an inner diameter of $0.015 \mathrm{~m}$ and outer diameter of $0.02 \mathrm{~m}$, with 98 revolutions spaced at $0.1 \mathrm{~m}$. The @ Source-Energy pipe was centered in the $\mathrm{x}$ and $y$-axis directions in the soil block and placed initially 3 meters below the ground surface. The soil block was modelled with a $0.01 \mathrm{~m}$ tetrahedral sized mesh, the cylindrical and helical pipe are modelled with a $0.001 \mathrm{~m}$ tetrahedral sized mesh. These distances were verified by the element quality analysis included in COMSOL by analyzing the skewness of 0.64 , volume versus circumradius of 0.65 , and condition number of 0.81 . An element in COMSOL is defined as a 3D shape, tetrahedral in this study, which is comprised of specific nodes in order to subdivide the domain. The skewness is based on the equiangular skew that compares angle size to the angles of an ideal element. An element with angles too large or too small causes numerical errors while simulating. The volume versus circumradius value is based on a quotient of the element volume and the radius of the circumscribed sphere of the element, which is sensitive to large angles, small angles, and anisotropy. The condition number quality measure is based on properties of the matrix transforming the actual element to an ideal element (COMSOL Multiphysics, 2017). Since the element quality analysis values below 0.1 are considered poor quality, this validates the mesh used in this study (COMSOL Multiphysics, 2007). 

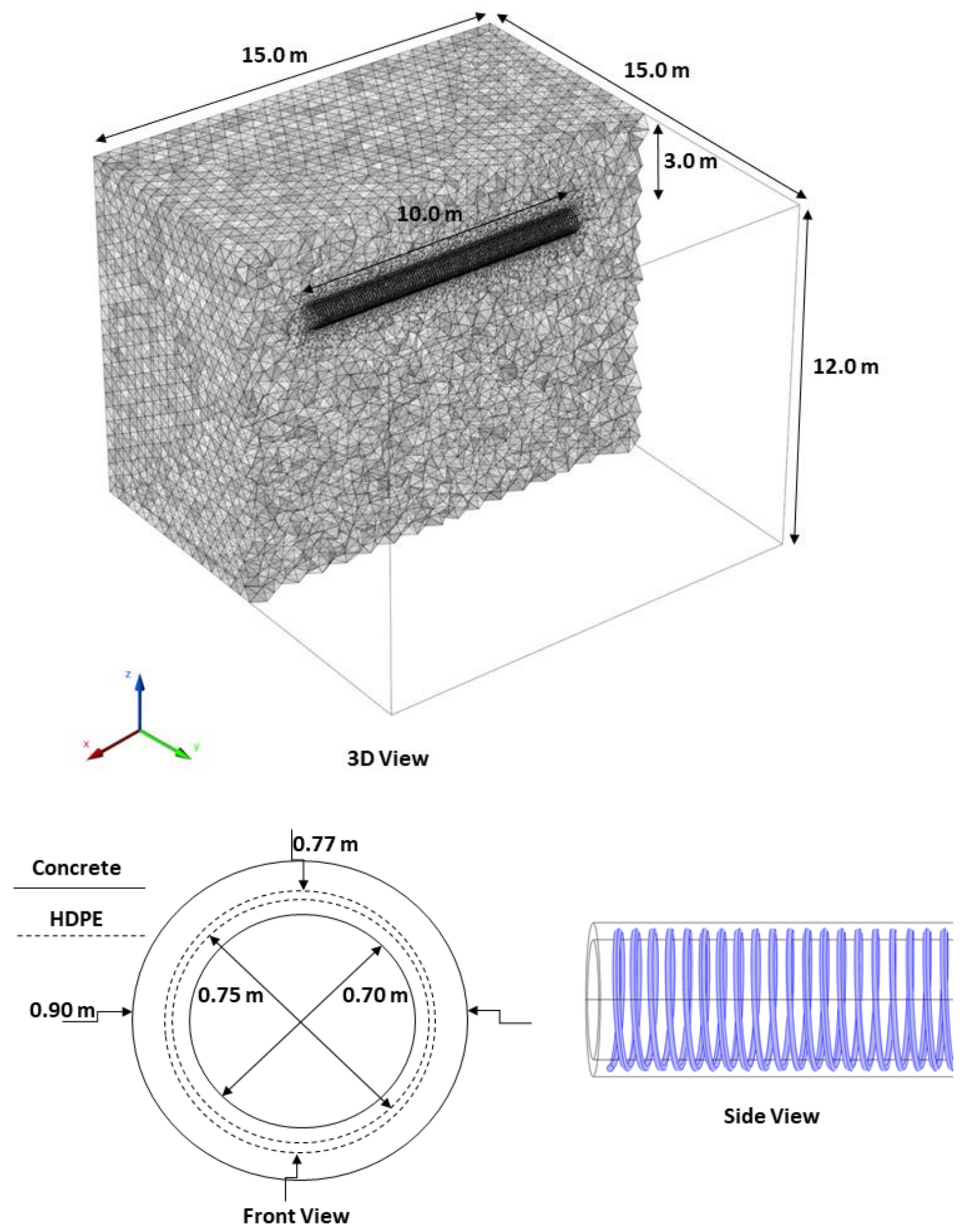

Figure 1: 3D, front and side schematic of numerical domain. 
A 3D time-dependent study was completed with a simulation time of 25 years with 1day time steps in order to evaluate the sustainability of the heat extraction system. This was based on the average lifespan of a geothermal heat pump of 20+ years (U.S. Department of Energy, 2011). The site-specific study was based in Winnipeg, Manitoba. Temperature data was extracted from the models and plotted with the modelled natural conditions at seven distinct points, 0.1, 0.2, 0.35, 0.5, $1.0 \mathrm{~m}$ adjacent to the @ Source-Energy pipe. To further analyze the sustainability, data was extracted from $1.0 \mathrm{~m}$ above and below the @Source-Energy pipe. The results were analyzed by calculating the average temperature change (ATC) and the temperature difference at the beginning and end of heating seasons $\left(\Delta \mathrm{T}_{\max }\right)$. The ATC values were calculated by the difference between the natural condition soil temperatures and the heat extraction system implementation in order to determine the effect of the system on the adjacent soil compared to the distance from the system. The energy balances were analyzed along with the total amount of energy extracted over the simulations from the climatic, subsurface, and sewage heat fluxes. The average monthly heat energy entering the system during the heating and cooling seasons was calculated based on the constant inlet and simulated outlet temperatures from the heat pump and using the Carnot equations (Callendar, 1911):

$$
C O P=\frac{T_{H}}{T_{H}-T_{L}}=\frac{Q_{H}}{W_{\text {in }}}
$$

where COP is the coefficient of performance, $\mathrm{T}_{\mathrm{H}}$ is the high temperature source in $[\mathrm{K}], \mathrm{T}_{\mathrm{L}}$ is the low temperature source in $[\mathrm{K}], \mathrm{Q}_{\mathrm{H}}$ is the desired output in $[\mathrm{kWhr}]$ and $\mathrm{W}_{\text {in }}$ is the work required in $[\mathrm{kWhr}]$. The calculated work required was used to evaluate the $\mathrm{CO}_{2}$ emissions 
reductions and the cost savings in Section 4.6. It was calculated based on the energy consumption from a natural gas furnace and AC unit from a typical middle-class Canadian Prairie home (Manitoba Hydro, 2019b). The cost savings were derived from the Manitoba cost of electricity of $8.196 \notin / \mathrm{kWh}$ and the Manitoba cost of natural gas of $7.62 \varnothing / \mathrm{m}^{3}$ (Manitoba Hydro, 2019a). The $\mathrm{CO}_{2}$ emissions reductions were derived from standard conversions for natural gas and kWh (United States Environmental Protection Agency, 2017).

\subsection{Model assumptions}

In the model, it was assumed that the heat exchange fluid inlet temperature is $1{ }^{\circ} \mathrm{C}$ for the heating seasons (Liu, Maghoul, \& Holländer, 2019). During the cooling seasons, the heat exchange fluid inlet temperature was assumed as $20^{\circ} \mathrm{C}$ (Manitoba Hydro, 2009). Saaly, Maghoul, Kavgic, and Polyzois (2019) concluded the heating months range from October to April and the cooling months range from May to September in Winnipeg; these conditions were assumed for this study. An initial trial was performed by implementing a $15^{\circ} \mathrm{C}$ temperature boundary condition at the inlet of the sewage pipe and analyzing the change in outlet temperatures based on the heat transfer along the pipe. The results showed a $0.87 \%$ difference in inlet and outlet temperature which led to the assumption of constant sewage temperature. Additionally, due to the lack of available data for the thermal properties of wastewater, the fluid was assumed to have the thermal properties of water at $15^{\circ} \mathrm{C}$. The obtained temperatures of the sewage water at the inflow of a wastewater treatment plant located in Winnipeg varied between $13.5-16.5^{\circ} \mathrm{C}$ over a 3-year time period (20162018) which led to the assumption of a constant $15^{\circ} \mathrm{C}$ sewage temperature (City of Winnipeg, 2019). Based on the average property size of a house in Winnipeg, an assumed length of $10 \mathrm{~m}$ of @ Source-Energy pipe was used to analyze each household. The energy 
demand used was based on a natural gas furnace and AC unit from a typical middle-class Canadian Prairie home (Manitoba Hydro, 2019b) (Table 1). An isotropic subsurface condition and constant thermal properties for saturated clay were assumed due to the horizontal placement of the heat extraction system within the subsurface and the relatively constant stratigraphy of glaciolacustrine clay from $2 \mathrm{~m}$ to $20 \mathrm{~m}$ in depth from ground surface in Winnipeg (Betcher, Grove, \& Pupp, 1995). Lastly, groundwater flow was deemed negligible due to the low permeability of the clayey subsurface conditions (Kjartanson, 1983).

Table 1: Monthly loads from the natural gas (NG) furnace and AC unit of a typical middle-class Canadian Prairie home (Manitoba Hydro, 2019b).

\begin{tabular}{lrr}
\hline Month & Heating demand $\left(\mathrm{m}^{3} \mathrm{NG}\right)$ & Cooling demand $(\mathrm{kWh})$ \\
\hline January & 453.5 & 0.0 \\
\hline February & 450.5 & 0.0 \\
\hline March & 260.2 & 0.0 \\
\hline April & 271.4 & 0.0 \\
\hline May & 58.8 & 1050.0 \\
\hline June & 61.6 & 1430.0 \\
\hline July & 25.2 & 1440.0 \\
\hline August & 42.0 & 1490.0 \\
\hline September & 53.2 & 0.0 \\
\hline October & 2514.9 & 0.0 \\
\hline November & 226.7 & 0.0 \\
\hline December & & 0.0 \\
\hline Total & & \\
\hline & & \\
\hline
\end{tabular}




\subsubsection{Governing Equations}

In all GHE applications, the surrounding soil acts as a heat sink from external forced convective heat transfer. The averaged heat transfer coefficient by external forced convection is characterized by Welty, Rorrer, and Foster (2014):

$$
\begin{aligned}
& N= \begin{cases}2 \frac{\lambda}{L} \frac{0.3387 \operatorname{Pr}^{\frac{1}{3}} R e_{L}^{\frac{1}{2}}}{\left(1+(0.0468 / P r)^{\frac{2}{3}}\right)^{\frac{1}{4}}} & R e_{L} \leq 5 \cdot 10^{5} \\
2 \frac{\lambda}{L} \operatorname{Pr}^{\frac{1}{3}}\left(0.037 R e_{L}^{\frac{4}{5}}-871\right) & R e_{L}>5 \cdot 10^{5}\end{cases} \\
& \text { where } \operatorname{Pr}=0.7 \text { and } \quad R e_{L}=\frac{\rho\left|U_{\text {ext }}\right| L}{\mu}
\end{aligned}
$$

where $L$ is the characteristic length $[\mathrm{m}], \lambda$ is the thermal conductivity $[\mathrm{W} /(\mathrm{m} \cdot \mathrm{K})]$ and $\mathrm{N}$ is the heat transfer coefficient $\left[\mathrm{W} /\left(\mathrm{m}^{2} \cdot \mathrm{K}\right)\right]$. Pr stands for the Prandtl number of air, which is taken as 0.7 for this case. $\mathrm{Re}_{\mathrm{L}}$ is the Reynolds number based on the characteristic length $\mathrm{L}$ where $\rho$ is the density of the fluid $\left[\mathrm{kg} / \mathrm{m}^{3}\right], \mathrm{U}_{\text {ext }}$ is the velocity of the fluid with respect to the ground surface $[\mathrm{m} / \mathrm{s}]$, and $\mu$ is the viscosity of the fluid $\left[\mathrm{m}^{2} / \mathrm{s}\right]$. The governing equation for the heat transfer through the concrete, HDPE pipe and soil domain is described below:

$$
\rho C_{p p}^{p h} \frac{\partial T}{\partial t}+\nabla \cdot \mathrm{q}=Q
$$

where $\rho$ is the density $\left[\mathrm{kg} / \mathrm{m}^{3}\right], C_{p p}^{p h}$ is the apparent heat capacity from Eq. $10[\mathrm{~J} /(\mathrm{kg} \cdot \mathrm{K})], \mathrm{T}$ is temperature $[\mathrm{K}], \mathrm{Q}$ is from Eq. $5\left[\mathrm{~W} / \mathrm{m}^{3}\right]$ which represents the coupling effect between the interface of pipe flow and HDPE. This allows for a computation for the heat exchange fluid temperature based on the heat transfer in surrounding materials. $\mathrm{q}$ is the conductive heat flux as defined by Fourier's law $\left[\mathrm{W} / \mathrm{m}^{2}\right]$ which is used in Eq. 3 to calculate the heat transfer in each material whereas the energy exchange is determined through the calculation of Q. Fourier's law is calculated as follows: 


$$
q=-k \nabla T
$$

where $\mathrm{q}$ is proportional to the temperature gradient $[\nabla T]$. In order to couple the heat transfer in solids with the heat transfer from pipe flow, the heat balance equation for an incompressible fluid flowing in a pipe is required:

$$
\rho A C_{p p}^{p h} \frac{\partial T}{\partial t}+\rho_{f} A C_{p f} u \nabla \mathrm{T}=\nabla \mathrm{A} \lambda_{f} \nabla \mathrm{T}+\frac{\rho A}{2 d_{h}}|u|^{3}-Q A
$$

where $\rho_{\mathrm{f}}$ is the fluid density $\left[\mathrm{kg} / \mathrm{m}^{3}\right], \mathrm{A}$ is the pipe cross-sectional area $\left[\mathrm{m}^{2}\right], C_{p f}$ is the specific heat capacity of the fluid $[\mathrm{J} /(\mathrm{kg} \cdot \mathrm{K})]$, T is temperature $[\mathrm{K}], \mathrm{u}$ is the velocity vector of translational motion $[\mathrm{m} / \mathrm{s}], \lambda_{\mathrm{f}}$ is the thermal conductivity of the fluid $[\mathrm{W} /(\mathrm{m} \cdot \mathrm{K})], \mathrm{d}_{\mathrm{h}}$ is the hydraulic diameter $[\mathrm{m}]$, and Q is the additional heat source $\left[\mathrm{W} / \mathrm{m}^{3}\right]$.

Phase change within the soil is a critical phenomenon that governs the heat exchange performance of the @Source-Energy pipe system. The governing equation for phase change effects in the soil is as follows:

$$
\rho^{\rho h} C_{p}^{\rho h} \frac{\partial T}{\partial t}=\nabla\left(\lambda^{\rho h} \nabla T_{s}\right)+Q+L_{f} \rho_{i} \frac{\partial \theta_{i}}{\partial T}
$$

where $\rho^{\rho h}$ is the soil density with phase change $\left[\mathrm{kg} / \mathrm{m}^{3}\right], C_{p}^{\rho h}$ is the specific heat capacity with phase change $[\mathrm{J} /(\mathrm{kg} \cdot \mathrm{K})], \mathrm{T}_{\mathrm{s}}$ is the temperature of the soil $[\mathrm{K}], \mathrm{t}$ is time $[\mathrm{s}], \lambda^{\rho h}$ is the thermal conductivity with phase change $[\mathrm{W} /(\mathrm{m} \cdot \mathrm{K})], \mathrm{Q}$ is the heat source $\left[\mathrm{W} / \mathrm{m}^{3}\right], \rho_{i}$ is the density of ice $\left[\mathrm{kg} / \mathrm{m}^{3}\right], \theta_{i}$ is the volumetric ice content of the soil, and $L_{f}$ is the latent heat released at phase change taken as $333 \mathrm{~kJ} / \mathrm{kg}$. In order to solve for $\rho^{\rho h}$, the following equation is needed:

$$
\rho^{\rho h}=\rho_{w} \theta_{w}+\rho_{i} \theta_{i}+\rho_{s}\left(1-\theta_{s}\right)
$$


where $\rho_{w}$ is the density of water $\left[\mathrm{kg} / \mathrm{m}^{3}\right], \theta_{w}$ is the unfrozen volumetric water content, $\rho_{s}$ is the density of soil skeleton $\left[\mathrm{kg} / \mathrm{m}^{3}\right]$, and $\theta_{s}$ is the saturated volumetric water content.

Similarly, $C_{p}^{\rho h}$ is calculated by the following:

$$
C_{p}^{\rho h}=C_{p w} \theta_{w}+\rho_{i} C_{p i}+C_{p s}\left(1-\theta_{s}\right)
$$

where $C_{p w}$ is the specific heat capacity of water $[\mathrm{J} /(\mathrm{kg} \cdot \mathrm{K})], C_{p i}$ is the specific heat capacity of ice $[\mathrm{J} /(\mathrm{kg} \cdot \mathrm{K})]$, and $C_{p s}$ is the specific heat capacity of the soil skeleton $[\mathrm{J} /(\mathrm{kg} \cdot \mathrm{K})]$.

Additionally, $\lambda^{\rho h}$ can be calculated:

$$
\lambda^{\rho h}=\lambda_{w} \theta_{w}+\lambda_{i} \theta_{i}+\lambda_{s}\left(1-\theta_{s}\right)
$$

where $\lambda_{w}$ is the thermal conductivity of water $[\mathrm{W} /(\mathrm{m} \cdot \mathrm{K})], \lambda_{i}$ is the thermal conductivity of ice $[\mathrm{W} /(\mathrm{m} \cdot \mathrm{K})]$, and $\lambda_{s}$ is the thermal conductivity of the soil skeleton $[\mathrm{W} /(\mathrm{m} \cdot \mathrm{K})]$. The apparent heat capacity of the soil $\left(C_{p p}^{\rho h}\right)$ can be defined by the following:

$$
C_{p p}^{\rho h}=\frac{\rho_{w} C_{p w} \theta_{w}+\theta_{i} \rho_{i} C_{p i}+\rho_{s}\left(1-\theta_{s}\right) C_{p s}-L_{f} \rho_{i} \frac{\partial \theta_{i}}{\partial T}}{\rho^{\rho h}}
$$

In order to calculate the unfrozen volumetric water content, the following equation is used derived by Zhu and Michalowski (2005):

$$
\theta_{w}=\theta_{r}+\left(\theta_{w o}-\theta_{r}\right) e^{a\left(T-T_{0}\right)}
$$

where $\theta_{r}$ is the residual volumetric water content taken at $0.05, \theta_{w o}$ is initial volumetric water content taken as 0.4 , a is a curve fitting parameter taken as 0.16 , and $\mathrm{T}_{0}$ is the freezing temperature of the saturated soil. 


\subsection{Model Setup}

\subsubsection{Initial and boundary conditions}

The research area was focused in Winnipeg, Manitoba, Canada with an initial soil temperature of $7^{\circ} \mathrm{C}$ (Ferguson \& Woodbury, 2004). Winnipeg has acontinental climate with vast variation between air temperatures in winter versus summer. The mean daily temperatures range from $-16.4^{\circ} \mathrm{C}$ in January to $19.7^{\circ} \mathrm{C}$ in July (Government of Canada, 2019). To simulate climatic heat transfer, an external forced convective heat flux was applied to the ground surface of the model. This boundary condition used the average daily temperature, wind velocity and absolute pressure which were obtained from the weather station at the Winnipeg International Airport from 1980-2005 to simulate 25 years (Government of Canada, 2019). The bottom of the domain was defined at a depth of $12 \mathrm{~m}$ as a constant heat flux boundary condition of $35 \mathrm{~mW} / \mathrm{m}^{2}$ (Jessop \& Judge, 1971) to simulate the subsurface heat flow. The sides of the domain were defined as an isothermal boundary condition. The sewage was also represented with a constant temperature of $15^{\circ} \mathrm{C}$ based on averaged sewage water inflow data. The heat exchange fluid inlet was modelled with a constant temperature of $1{ }^{\circ} \mathrm{C}$ during the heating season (Liu et al., 2019) and with $20^{\circ} \mathrm{C}$ during cooling season (Saaly et al., 2019).

\subsubsection{Parameterization}

The clay subsurface has a porosity of 0.40 (Kjartanson, 1983). The thermal properties of the concrete were determined by taking values of a standard mix collected by Bergman, 
Lavine, Incropera, and Dewitt (2007). The thermal properties of the embedded HDPE in concrete were taken from Hafeez and Abdalla (1972) and the thermal properties of the $30 \%$ ethylene glycol-water blend heat exchange fluid were taken from Melinder (2007). All thermal properties are summarized in Table 2 . The dynamic viscosity of the water at $15^{\circ} \mathrm{C}$ was $0.001 \mathrm{~kg} /(\mathrm{m} \cdot \mathrm{s})$. The surface roughness of the HDPE pipe used was $0.0015 \mathrm{~mm}$ (Farshad, Rieke, \& James, 2001). For the analysis of the differential sewage temperature within the pipe, the sewage flow rate was measured as $0.83 \mathrm{~m} / \mathrm{s}$ from the South End Sewage Treatment Plant (SEWPCC) in Winnipeg and verified by standard slopes for gravity-fed sewage systems (Mihelcic \& Zimmerman, 2014). The volumetric flow rate of the heat exchange fluid was 13 1/min (Shin \& Cho, 2018).

Table 2: Thermal properties of model materials (Bergman et al., 2007; Hafeez \& Abdalla, 1972; Melinder, 2007; Zhu \& Michalowski, 2005).

\begin{tabular}{lccc}
\hline Material & $\begin{array}{c}\text { Thermal conductivity } \\
(\mathrm{W} /(\mathrm{m} \cdot \mathrm{K}))\end{array}$ & Density $\left(\mathrm{kg} / \mathrm{m}^{3}\right)$ & $\begin{array}{c}\text { Heat capacity } \\
(\mathrm{J} /(\mathrm{kg} \cdot \mathrm{K}))\end{array}$ \\
\hline Concrete & 1.42 & 2290 & 880 \\
\hline Water & 0.59 & 1000 & 2000 \\
\hline HDPE & 0.26 & 950 & 2960 \\
\hline Clay (soil skeleton) & 1.00 & 2650 & 2040 \\
\hline Ice & 1.88 & 920 & 4250 \\
\hline $30 \%$ Ethylene glycol Wa- & 0.41 & 955 & \\
ter Blend & & & \\
\hline
\end{tabular}




\subsubsection{Sensitivity Analysis}

The sensitivity analysis performed on the clay thermal properties shows strong evidence against an influence from a varying soil types on the sustainability of the @ Source-Energy pipe (Table 3).

Table 3: Correlation coefficients for sensitivity analysis on clay thermal properties $\pm 50 \%$ against original properties.

\begin{tabular}{lcccccc}
\hline Thermal Property & $\rho+50 \%$ & $\rho-50 \%$ & $\lambda+50 \%$ & $\lambda-50 \%$ & $C_{p}+50 \%$ & $C_{p}-50 \%$ \\
\hline Correlation Coefficient & 0.96 & 0.93 & 0.95 & 0.95 & 0.96 & 0.93 \\
\hline
\end{tabular}

A $\pm 50 \%$ adjustment is made to include a variety of thermal properties within the subsurface and to analyze the effect of various soil types. One soil layer was considered and the thermal parameters were changed individually. Table 3 shows no significant effect on the sustainability of the @Source-Energy pipe from the differential thermal properties of soil and can be deemed as non-critical due to the relatively high correlation coefficients compared to the thermal performance of the system with the original properties. This validates the assumption of isotropic subsurface conditions and constant thermal properties.

\subsubsection{Sustainability Target}

The sustainability of the system was based on an experiment in Prague, Czech Republic (Neuberger et al., 2014). The author's study presented results on a horizontal slinkytype ground source heat exchanger as a source for three $13.3 \mathrm{~kW}$ heat pumps within a climate with an annual air temperature difference of $25^{\circ} \mathrm{C}$. The study concluded that the 
maximum temperature difference at the beginning and end of heating seasons $\left(\Delta \mathrm{T}_{\max }\right)$ did not exceed $2{ }^{\circ} \mathrm{C}$ within the four-year measurement period. The annual temperature difference is significantly lower than the annual temperature difference seen in the Canadian Prairies. This allows for the confirmed sustainability of the ground heat exchanger studied within this paper due to the challenges of thermal balancing of GHE's in a cold climate. In this study, the sustainability of the system based on a 25 -year simulation is evaluated based on the average lifespan of a geothermal heat pump of 20+ years (U.S. Department of Energy, 2011).

\subsection{Results and discussions}

\subsubsection{Model Validation}

In order to validate the subsurface temperatures of the natural conditions, a simulation was performed without the heat extraction system to measure the temperature distribution from the surface climatic heat flux and bottom constant heat flux boundary condition. Due to the non-uniform subsurface distribution of temperature throughout the extreme climate of Winnipeg, frost depth was determined as the standard to measure the accuracy of the model. The observed frost depth was 1.2 to $2.1 \mathrm{~m}$, whereas the simulated frost depth showed values of 1.3 to $1.7 \mathrm{~m}$ (Table 4). As stated by the City of Winnipeg for the measurement of the recorded frost depths: "This number is determined based on the best available information (e.g., water and sewer excavations). Frost depth is highly variable across the city, often differing from street to street." (City of Winnipeg, 2017). Due to this, the 
simulated frost depth over 4 years were averaged, compared, and showed a reasonable match with the observed depths.

Table 4: Comparison of reported City of Winnipeg and simulated frost depth (City of Winnipeg, 2017, 2018).

\begin{tabular}{lccccc}
\hline Year & $2014 / 15$ & $2015 / 16$ & $2016 / 17$ & $2017 / 18$ & Average \\
\hline Frost Depth - City of Winnipeg (m) & 2.1 & 1.2 & - & 1.2 & 1.5 \\
\hline Frost Depth - Simulated (m) & 1.7 & 1.3 & 1.6 & 1.4 & 1.5
\end{tabular}

The phase change model was validated by comparing results with a study performed by Zhu and Michalowski (2005). The change in frost depth over a $7 \mathrm{~cm}$ sample based on the 1-dimensional soil freezing problem governed by the phase change Eq.'s 6-11 showed a match in results with a correlation coefficient of 0.98 . In both cases, the heat transfer caused the frost depth to drop rapidly during the first half an hour and then reached a pseudo-steady state. In the simulated case, pseudo-steady state was obtained after 9 hours, whereas the literature case took 7 hours thus validating the phase change model for this study.

In order to validate the heat transfer in the pipes model, a case study from Saga City, Japan was used where a horizontal ground heat exchanger was installed, tested, and validated using a numerical model (Fujii, Tsuya, Harada, \& Kosukegawa, 2019). The numerical simulation was performed over a period of 48 hours and analyzed the outlet temperatures between numerical and experimental results. The directional heat exchanger in the numerical simulation was modelled in COMSOL Multiphysics and the calculated outlet temperatures were analyzed. The calculated outlet temperatures match the measured temperatures produced from the author's results with a correlation coefficient of 0.99 . Both 
the measured and calculated outlet temperatures increased exponentially during the first 6 hours then incrementally increased until 24 hours. Proceeding, the temperatures remained steady until 42 hours then decreased slightly before increasing exponentially. The accuracy between the author's measured outlet temperatures and the simulated outlet temperatures validated the heat transfer in pipes model for this study.

\subsubsection{Long-term sustainability implications}

An analysis was performed on the heat extraction system embedded in the soil block that yielded the temperature difference at the beginning and end of heating seasons $\left(\Delta \mathrm{T}_{\max }\right)$ and the ATC compared to no geothermal usage. The ATC values calculated were the difference in soil temperatures between the natural conditions and the heat extraction system implementation. The results showed that the $\Delta \mathrm{T}_{\max }$ stayed relatively constant to an adjacent distance of $1.0 \mathrm{~m}$ (Table 5). Additionally, the $\Delta \mathrm{T}_{\max }$ below the pipe was $3.6 \%$ the magnitude as the $\Delta \mathrm{T}_{\max }$ above the pipe, which is attributed to the climatic heat flux affecting the shallower soil layers. However, since all $\Delta \mathrm{T}_{\max }$ values were less than $2^{\circ} \mathrm{C}$, the results indicated that the system is sustainable based on the sustainability target set. The ATC calculations decreased linearly with an $\mathrm{R}^{2}$ value of 0.816 as the distance from the heat extraction system increased. This result showed that there is a point at which there is no effect on adjacent soil temperature, which was determined at $4 \mathrm{~m}$ (Fig. 2). This is a critical design parameter that should be implemented when installing the @ Source-Energy pipe system. 
Table 5: Corresponding $\Delta \mathrm{T}_{\max }$ and ATC with distance from heat extraction system over 25 years.

\begin{tabular}{lccccccc}
\hline & \multicolumn{5}{c}{ Beside Pipe } & & Above Pipe \\
& \multicolumn{7}{c}{ Below Pipe } \\
\hline Distance from heat extraction system $(\mathrm{m})$ & 0.10 & 0.20 & 0.35 & 0.50 & 1.0 & 1.0 & 1.0 \\
\hline Heating Season $\Delta \mathrm{T}_{\max }\left({ }^{\circ} \mathrm{C}\right)$ & 0.08 & 0.05 & 0.06 & 0.10 & 0.10 & 0.28 & 0.01 \\
\hline ATC $\left({ }^{\circ} \mathrm{C}\right)$ & 8.89 & 6.34 & 5.98 & 4.63 & 4.93 & 3.76 & 5.24 \\
\hline
\end{tabular}

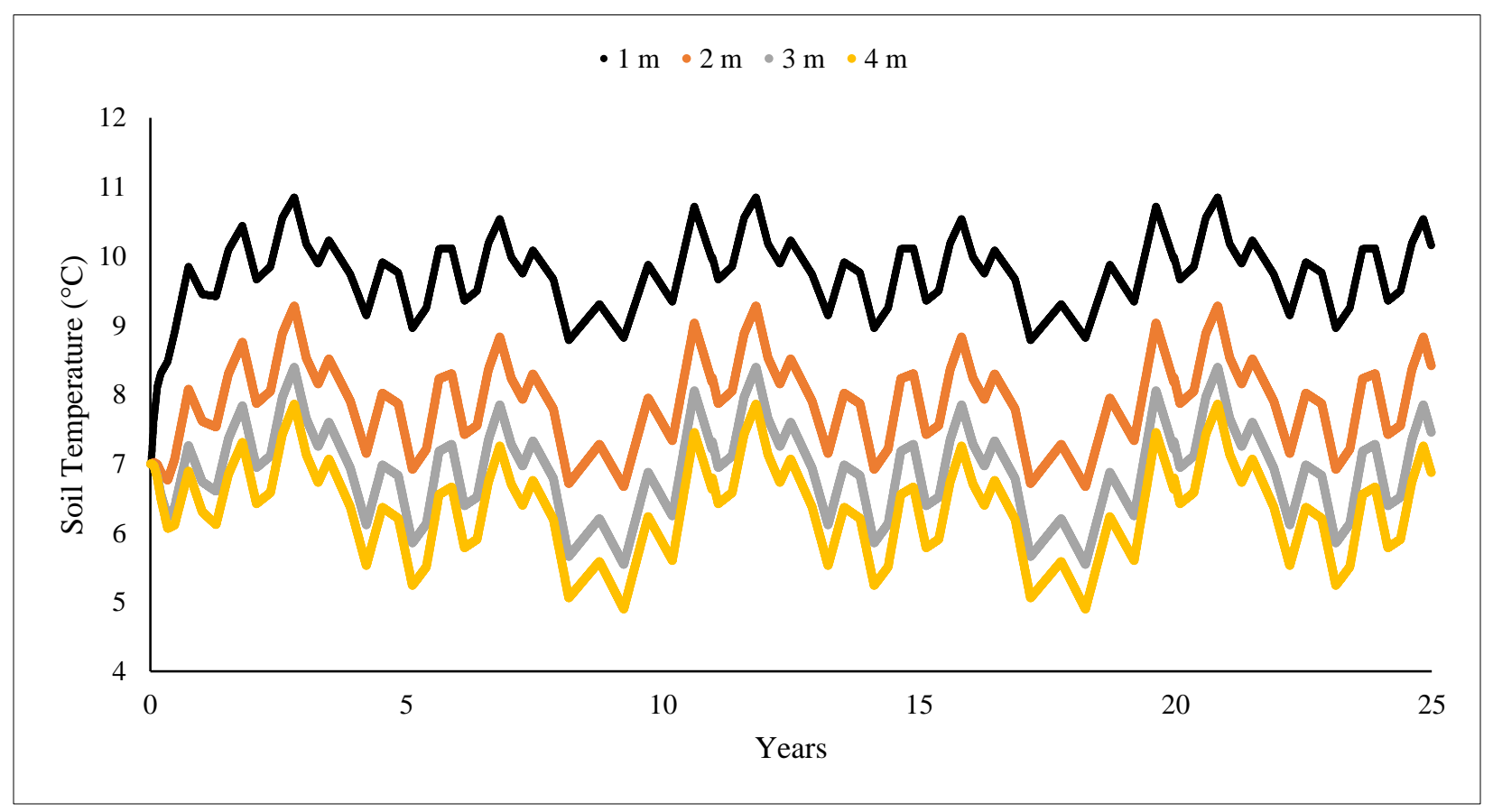

Figure 2: Soil temperatures adjacent to the system at $3 \mathrm{~m}$ depth.

The minimum temperature throughout the heating season when the heat extraction system was implemented remained stable at $13.1^{\circ} \mathrm{C}$ throughout the entire study (Fig. 3). During the heating season, the soil temperature was $8.9^{\circ} \mathrm{C}$ higher then the simulated natural conditions. This can be attributed to the conduction from the sewage heat within the pipe increasing the adjacent soil temperature due to the constant sewage temperature of $15^{\circ} \mathrm{C}$. When the sewage pipe system was implemented without heat extraction the adjacent soil 
temperatures increased. This shows the long-term thermal balancing of the system and indicates sustainability.

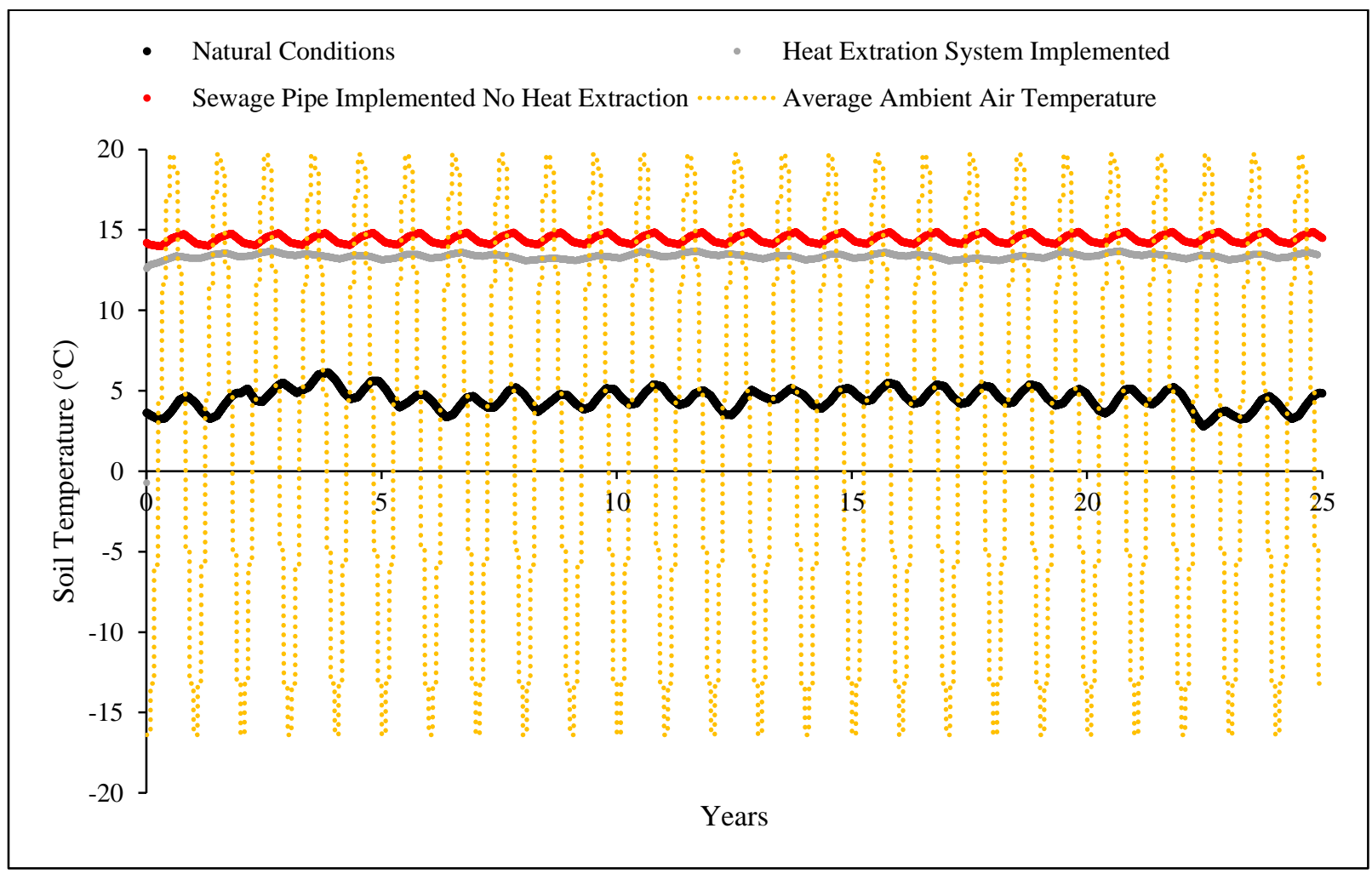

Figure 3: Soil temperatures at $0.1 \mathrm{~m}$ adjacent to the system at $3 \mathrm{~m}$ depth for various scenarios and air temperature.

In order to confirm directional uniformity, this phenomenon was analyzed $1.0 \mathrm{~m}$ above and below the system to determine vertical sustainability (Fig. 4). There was an increasing difference in temperature $1.0 \mathrm{~m}$ above the pipe compared to $1.0 \mathrm{~m}$ below due to the impact of the subsurface heat flux generating a constant temperature observed in that depth. The variable climatic heat flux affected the upper layer of the domain increasingly as the distance to the ground surface decreased. Since the $\Delta \mathrm{T}_{\max }$ was below the $2.0^{\circ} \mathrm{C}$ sustainability target from all analyzed soil locations, strong evidence towards sustainability was shown. 


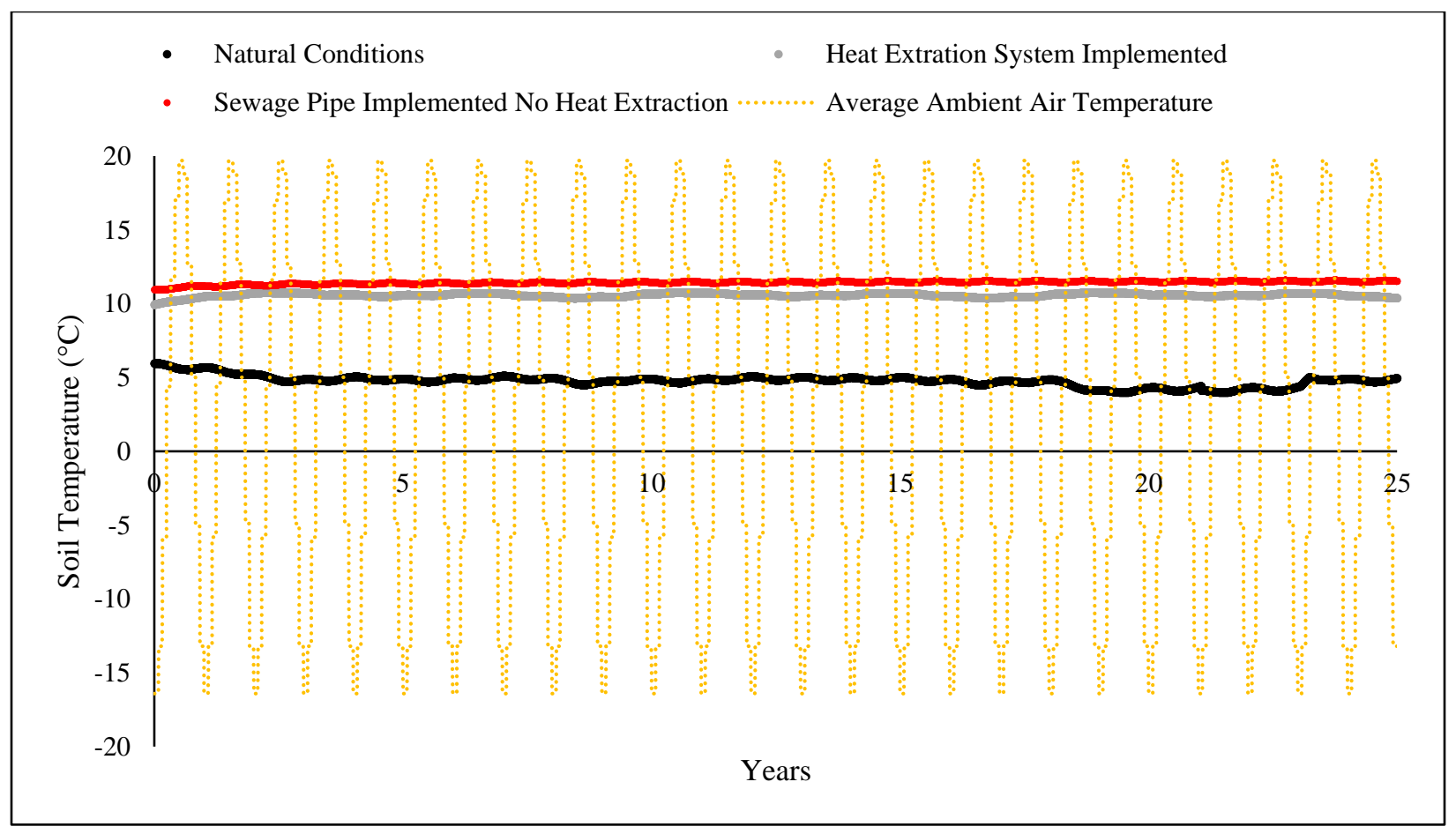

Figure 4: Soil temperatures at $1.0 \mathrm{~m}$ below the system for various scenarios and air temperature.

\subsubsection{Heating season}

A thermal balance between the heat extraction system and the sewage can be seen in Figs. 3 and 4. The temperature of the adjacent soil is consistently lower when the heat extraction system was implemented versus when it was not. This shows the sewage heat was utilized by the heat extraction system instead of being transferred into the adjacent soil. During the 25 -year study, $84 \mathrm{~kW} /$ year of energy was extracted from the sewage with an average of $22.75 \mathrm{~W} /(\mathrm{m} \cdot$ day $)$. Less than $3 \%(0.656 \mathrm{~W} /(\mathrm{m} \cdot$ day $))$ of additional energy was transferred from the subsurface below the pipe. The energy transferred below the pipe is comparable to the common values of heat extraction obtained from Verlag des 
Vereins Deutscher Ingenieure (2001). This standard states that $0.66 \mathrm{~W} /(\mathrm{m} \cdot$ day) can be extracted from clay, which verifies the values produced by the numerical model in this study.

\subsubsection{Cooling season}

The maximum temperature in Fig. 3 is $13.7^{\circ} \mathrm{C}$ and has an average difference in temperature of $7.9^{\circ} \mathrm{C}$ from the modelled natural conditions over the 25 -year test period within summer. Similarly, in Fig. 4, the maximum value can be seen as $10.7^{\circ} \mathrm{C}$, with an average difference in temperature of $5.1^{\circ} \mathrm{C}$. Strong temperature differentials established from heat extraction system can be attributed to the heat fluxes derived from the heat extraction system and the climatic conditions (Fig. 5). The average temperature in Winnipeg over the cooling season is $20^{\circ} \mathrm{C}$, therefore, a constant temperature gradient between the ground surface and the adjacent soil to the heat extraction system was established. 


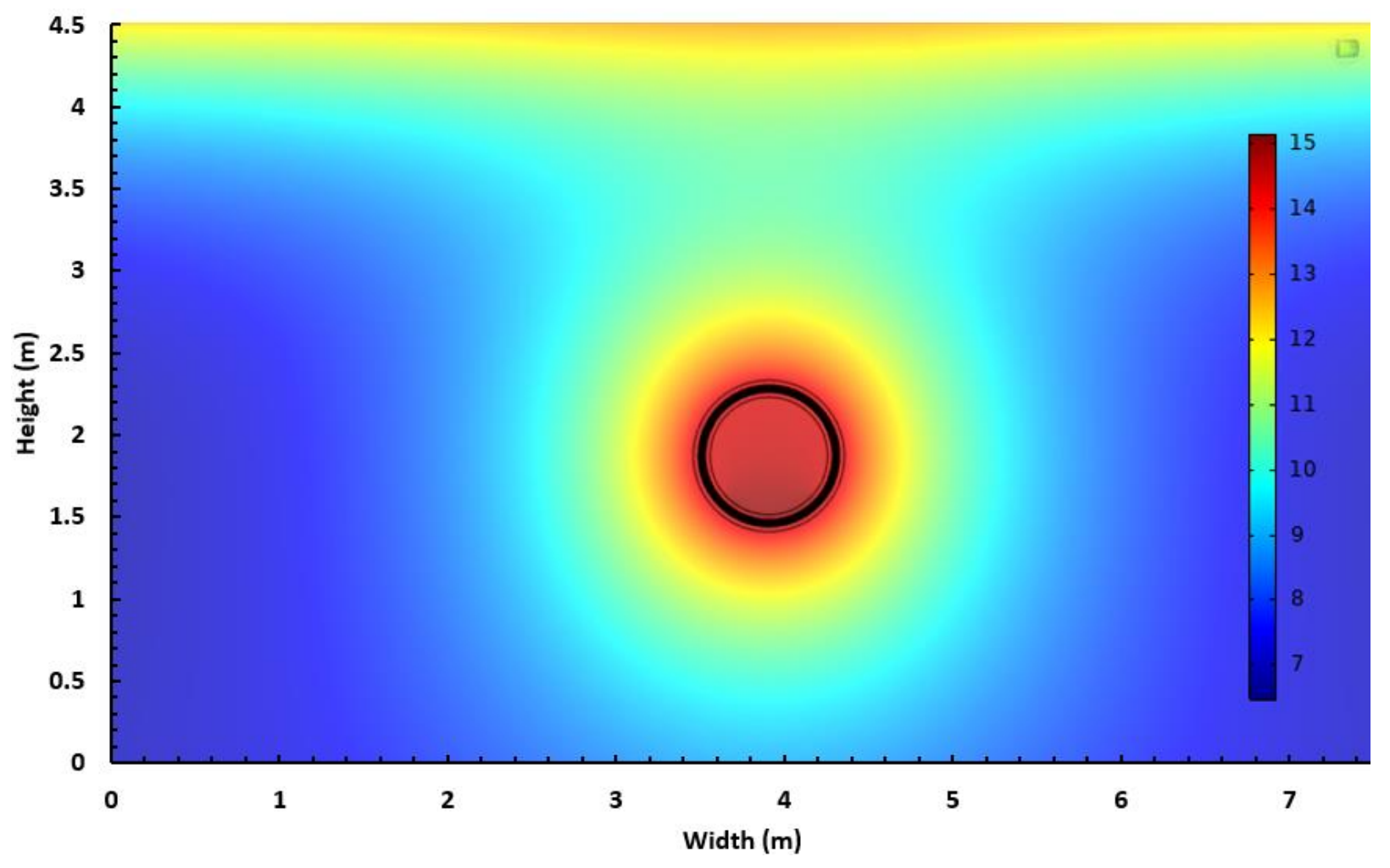

Figure 5: Soil temperature of the cross-section.

Fourier's law (eq. 2) states that as the temperature gradient increases, heat flux increases. Therefore, a more significant temperature differential between the ambient temperature and the heat extraction system is beneficial. The energy transferred from the atmosphere was $271.37 \mathrm{~kW} / \mathrm{year}$. This energy was used in a sustainable manner due to the additional heat supplemented from the sewage and was consistent throughout the 25-year period, therefore, showing thermal balancing over a long-term trial.

\subsubsection{Impact of system depth}

The $\Delta \mathrm{T}_{\max }$ at all studied depths remains within the sustainability threshold established at $2.0^{\circ} \mathrm{C}$ (Table 6). The ATC calculations show that as the depth increased, the ATC decreased. This phenomenon is due to the relatively constant temperature of soil adjacent to 
the heat extraction system due to the sewage heat and the increasingly constant soil temperature with increasing depth (Ferguson and Woodbury, 2004). As the system is installed deeper below the surface, it has the disadvantage of utilizing the subsurface constant temperature rather than the energy from the climatic heat flux. Over the 5-year study, the heat extraction system obtained an average of $156.85 \mathrm{~kW} /$ year of energy from the climatic heat flux at the $8 \mathrm{~m}$ depth. Although the system at the $8 \mathrm{~m}$ depth obtained $57 \%$ of the energy from the climatic heat flux as the $3 \mathrm{~m}$ depth simulation, the temperature profile of the adjacent soil remains similar (Fig. 6).

Table 6: Corresponding $\Delta \mathrm{T}_{\max }$ and ATC with distance from heat extraction system over 5 years at depths of 4, 5, 6, 7, and $8 \mathrm{~m}$.

\begin{tabular}{|c|c|c|c|c|c|c|c|c|}
\hline $\begin{array}{c}\text { Depth } \\
\text { (m) }\end{array}$ & & \multicolumn{4}{|c|}{ Beside Pipe } & \multicolumn{2}{|c|}{ Above Pipe } & $\begin{array}{c}\text { Below } \\
\text { Pipe }\end{array}$ \\
\hline \multirow{4}{*}{4} & Distance from heat extraction & 0.10 & 0.20 & 0.35 & 0.50 & 1.0 & 1.0 & 1.0 \\
\hline & system (m) & & & & & & & \\
\hline & Heating season $\Delta \mathrm{T}_{\max }\left({ }^{\circ} \mathrm{C}\right)$ & 0.07 & 0.12 & 0.13 & 0.13 & 0.15 & 0.11 & 0.03 \\
\hline & $\operatorname{ATC}\left({ }^{\circ} \mathrm{C}\right)$ & 7.51 & 7.00 & 6.14 & 5.54 & 4.11 & 4.04 & 4.23 \\
\hline \multirow{4}{*}{5} & Distance from heat extraction & 0.10 & 0.20 & 0.35 & 0.50 & 1.0 & 1.0 & 1.0 \\
\hline & system (m) & & & & & & & \\
\hline & Heating season $\Delta \mathrm{T}_{\max }\left({ }^{\circ} \mathrm{C}\right)$ & 0.08 & 0.08 & 0.21 & 0.22 & 0.24 & 0.01 & 0.02 \\
\hline & $\operatorname{ATC}\left({ }^{\circ} \mathrm{C}\right)$ & 7.26 & 6.71 & 6.03 & 5.01 & 4.04 & 4.02 & 4.12 \\
\hline \multirow{3}{*}{6} & Distance from heat extraction & 0.10 & 0.20 & 0.35 & 0.50 & 1.0 & 1.0 & 1.0 \\
\hline & system (m) & & & & & & & \\
\hline & Heating season $\Delta \mathrm{T}_{\max }\left({ }^{\circ} \mathrm{C}\right)$ & 0.11 & 0.13 & 0.15 & 0.21 & 0.30 & 0.01 & 0.03 \\
\hline
\end{tabular}




\begin{tabular}{|c|c|c|c|c|c|c|c|c|}
\hline & $\operatorname{ATC}\left({ }^{\circ} \mathrm{C}\right)$ & 7.08 & 6.48 & 5.89 & 4.93 & 4.03 & 3.98 & 4.04 \\
\hline & Distance from heat extraction & 0.10 & 0.20 & 0.35 & 0.50 & 1.0 & 1.0 & 1.0 \\
\hline \multirow[t]{4}{*}{7} & system $(\mathrm{m})$ & & & & & & & \\
\hline & Heating season $\Delta \mathrm{T}_{\max }\left({ }^{\circ} \mathrm{C}\right)$ & 0.08 & 0.16 & 0.15 & 0.22 & 0.21 & 0.23 & 0.17 \\
\hline & $\operatorname{ATC}\left({ }^{\circ} \mathrm{C}\right)$ & 7.05 & 6.51 & 5.69 & 5.00 & 3.98 & 4.24 & 4.05 \\
\hline & Distance from heat extraction & 0.10 & 0.20 & 0.35 & 0.50 & 1.0 & 1.0 & 1.0 \\
\hline \multirow[t]{3}{*}{8} & system (m) & & & & & & & \\
\hline & Heating season $\Delta \mathrm{T}_{\max }\left({ }^{\circ} \mathrm{C}\right)$ & 0.09 & 0.13 & 0.19 & 0.28 & 0.22 & 0.25 & 0.27 \\
\hline & $\operatorname{ATC}\left({ }^{\circ} \mathrm{C}\right)$ & 6.99 & 6.43 & 5.75 & 5.09 & 3.99 & 4.15 & 4.17 \\
\hline
\end{tabular}

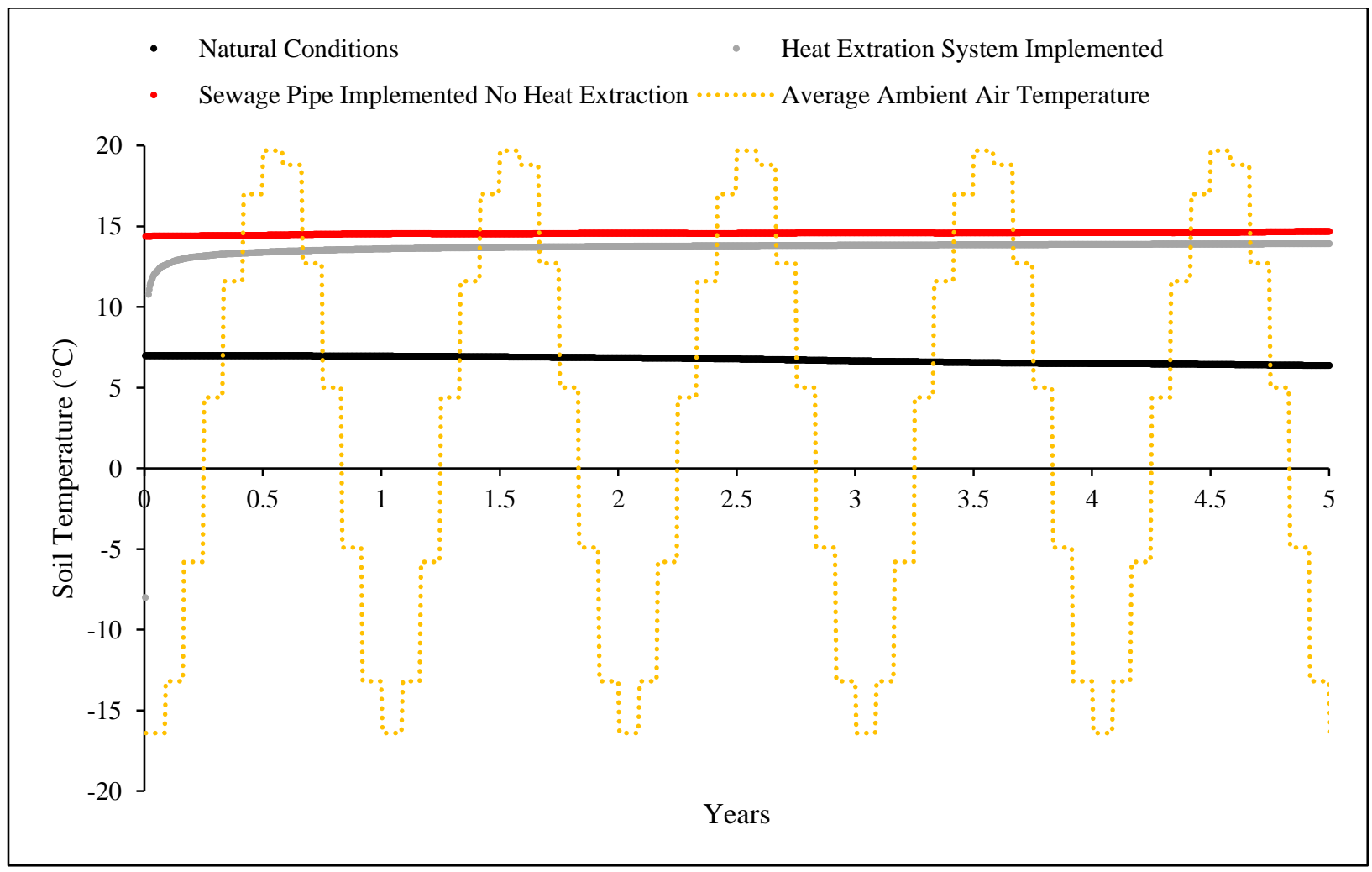

Figure 6: Difference between scenario-specific soil temperatures at $0.1 \mathrm{~m}$ from the system at $8 \mathrm{~m}$ depth and air temperature. 
The temperature lows of the adjacent soil fluctuated between $13.2^{\circ} \mathrm{C}$ and $13.3^{\circ} \mathrm{C}$ whereas the temperature highs remained relatively constant at $13.9^{\circ} \mathrm{C}$. The similarities in adjacent soil temperature can be attributed to the utilization of the sewage heat flux, which is not depth-dependent. This shows a thermal balance obtained at all depths studied and strong evidence towards sustainability for the @ Source-Energy pipe for a typical gravityassisted sewage system application.

\subsubsection{Impact of HDPE thermal properties}

Observation of Fig. 7 shows that the variation between curves is minimal and there is no apparent effect from the addition of the HDPE thermal properties between the modelled scenarios. In order to conclude this theory with strong evidence, further statistical analysis showed the correlation between the data sets was 0.93 , ATC was $0.09^{\circ} \mathrm{C}$, and the coefficient of determination was 0.86 . 


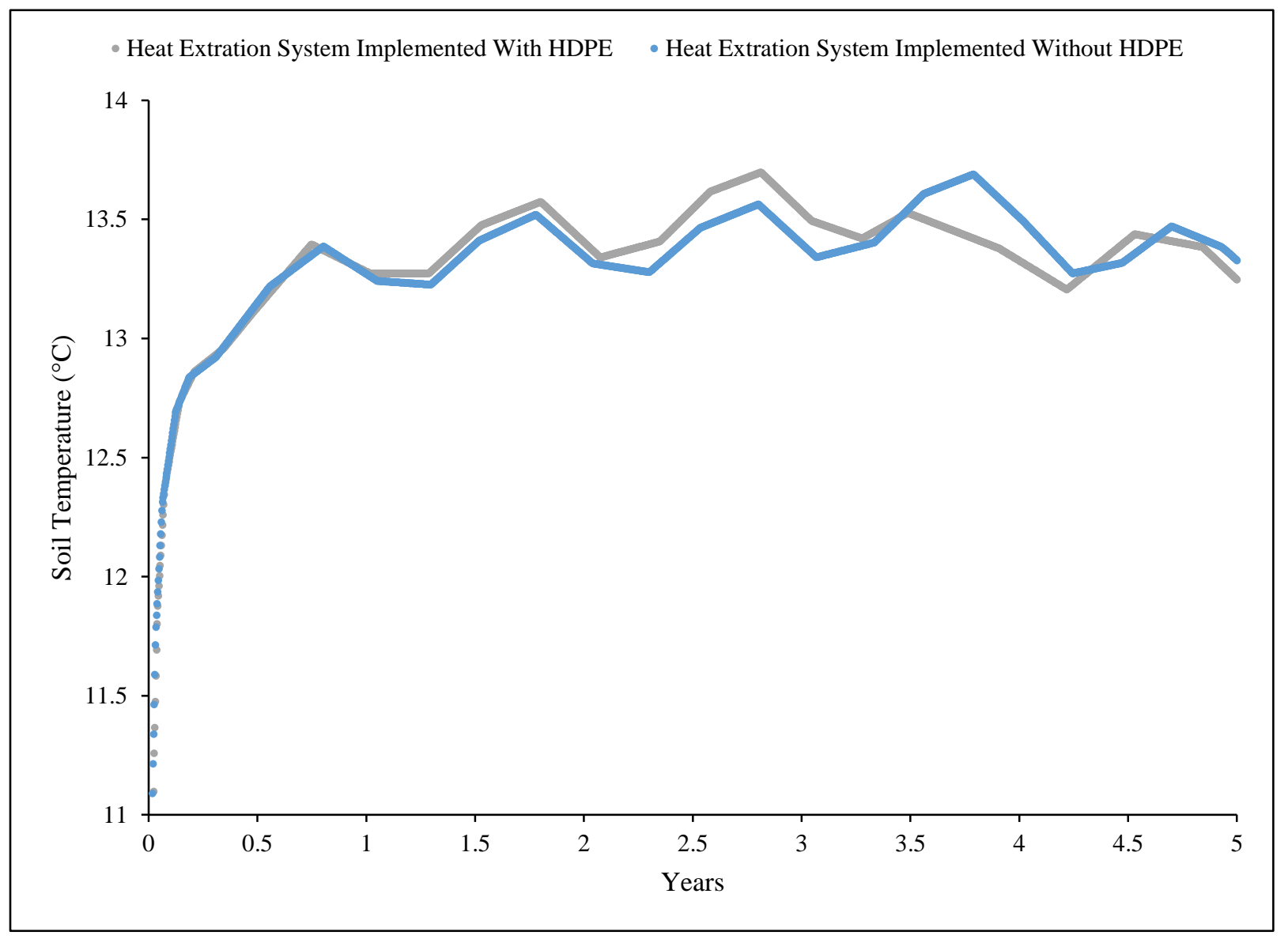

Figure 7: Difference between heat extraction system implementation with and without HDPE at $0.1 \mathrm{~m}$ from the system and $3 \mathrm{~m}$ depth.

Since this study used an inlet temperature function, which was used to analyze the temperatures in the soil surrounding the pipe, the thermal conductance is normal to the HDPE pipe. Due to this and the HDPE pipe thickness of $5 \mathrm{~mm}$, the effect of the heat transfer from conduction on the HDPE is minimal for the specific simulation. When multiplying the thermal conductivity with the thickness, the total thermal conductance is $0.0013 \mathrm{~W} / \mathrm{K}$ normal to the pipe. Due to the minuscule thickness, there is strong evidence as to why there 
is no apparent effect of the addition of the HDPE thermal properties in the simulated scenario. In a real-world application, the heat transfer would be a function of the length of the pipe. In a $10 \mathrm{~m}$ section of the @ Source-Energy pipe with HDPE pipe dimensions of an inner diameter of $0.015 \mathrm{~m}$, outer diameter of $0.02 \mathrm{~m}$, and 98 revolutions spaced at $0.1 \mathrm{~m}$; the total length is $126 \mathrm{~m}$. The total thermal conductance in the longitudinal direction is 32.8 $\mathrm{W} / \mathrm{K}$. This is significantly larger than the thermal conductance normal to the HDPE pipe. Instead of the main component of heat transfer in the scenario studied, the use of HDPE becomes a factor in terms of a mode of transportation for the heat exchange fluid. If the same design were utilized without the HDPE embedded in concrete, the heat exchange fluid would simply run through a pre-cast groove; which would lead to corrosion over time, therefore, reducing the lifespan of the system. Because of this, the HDPE is a significant component in the design despite its negligible heat transfer contributions for the scenario analyzed.

\subsubsection{Impact of sewage level}

When the sewage level was increased from $25 \%$ to $75 \%$ capacity of the pipe, the impact on the heat extraction systems sustainability was insignificant (Fig. 8). 


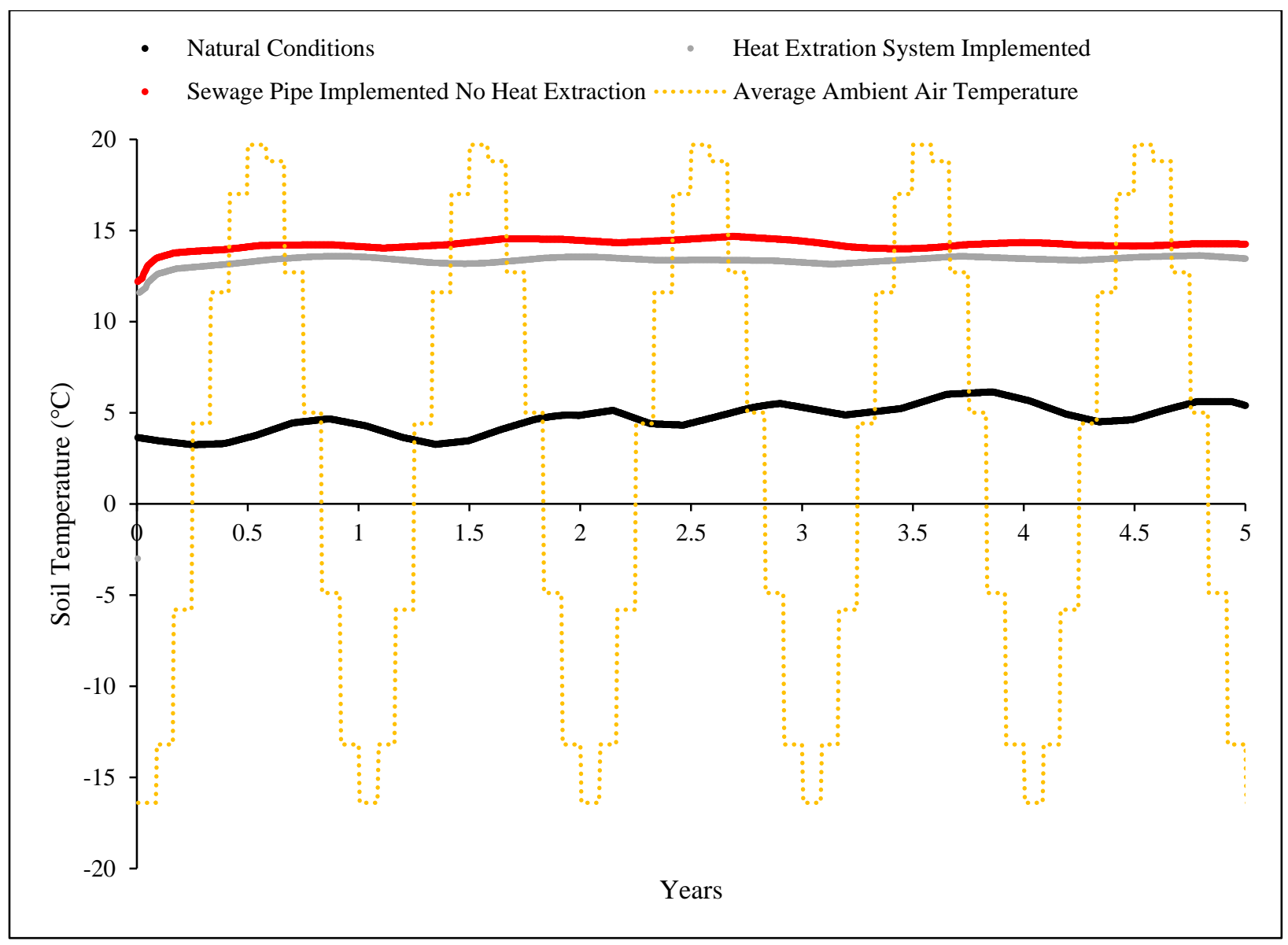

Figure 8: Difference between scenario-specific soil temperatures at $0.1 \mathrm{~m}$ from system at $3 \mathrm{~m}$ depth and air temperature with $75 \%$ sewage pipe capacity.

The temperature difference of the adjacent soil between the cooling season and heating season was $0.6^{\circ} \mathrm{C}$ for $75 \%$ sewage pipe capacity and $0.7^{\circ} \mathrm{C}$ for $25 \%$. This minimal change in amplitude can be attributed to the increased sewage heat flux utilized by the heat extraction system, which creates less dependency for additional heat transfer from adjacent soil in order to meet the same energy demand. The energy obtained from the sewage for the $75 \%$ sewage pipe capacity simulation was $25.2 \mathrm{~W} /(\mathrm{m} \cdot$ day) versus $24.8 \mathrm{~W} /(\mathrm{m} \cdot$ day) for the $50 \%$ simulation. This is a marginal increase compared to the $25 \%$ sewage pipe capacity at 
$22.8 \mathrm{~W} /(\mathrm{m} \cdot$ day), which can be attributed to the conduction between the interior of the concrete sewage pipe and the HDPE. At $25 \%$ sewage pipe capacity, the sewage provides adequate energy to heat the entire interior of the sewage pipe. This theory was validated by the $8.7 \%$ and $10.5 \%$ increase in sewage heat flux when the capacity was increased to $50 \%$ and $75 \%$ respectively. The results show the $\Delta \mathrm{T}_{\max }$ meets the sustainability target set and a decrease in ATC with increased adjacent distance from the system with similar results to the $25 \%$ sewage pipe capacity simulation (Table 7). This confirms sustainable behaviour in the case of an increase in sewage level due to natural causes such as storm water infiltration or increased sewage volume from municipal households.

Table 7: Corresponding $\Delta \mathrm{T}_{\max }$ and ATC with distance from heat extraction system over 5 years with $50 \%$ and $75 \%$ sewage level.

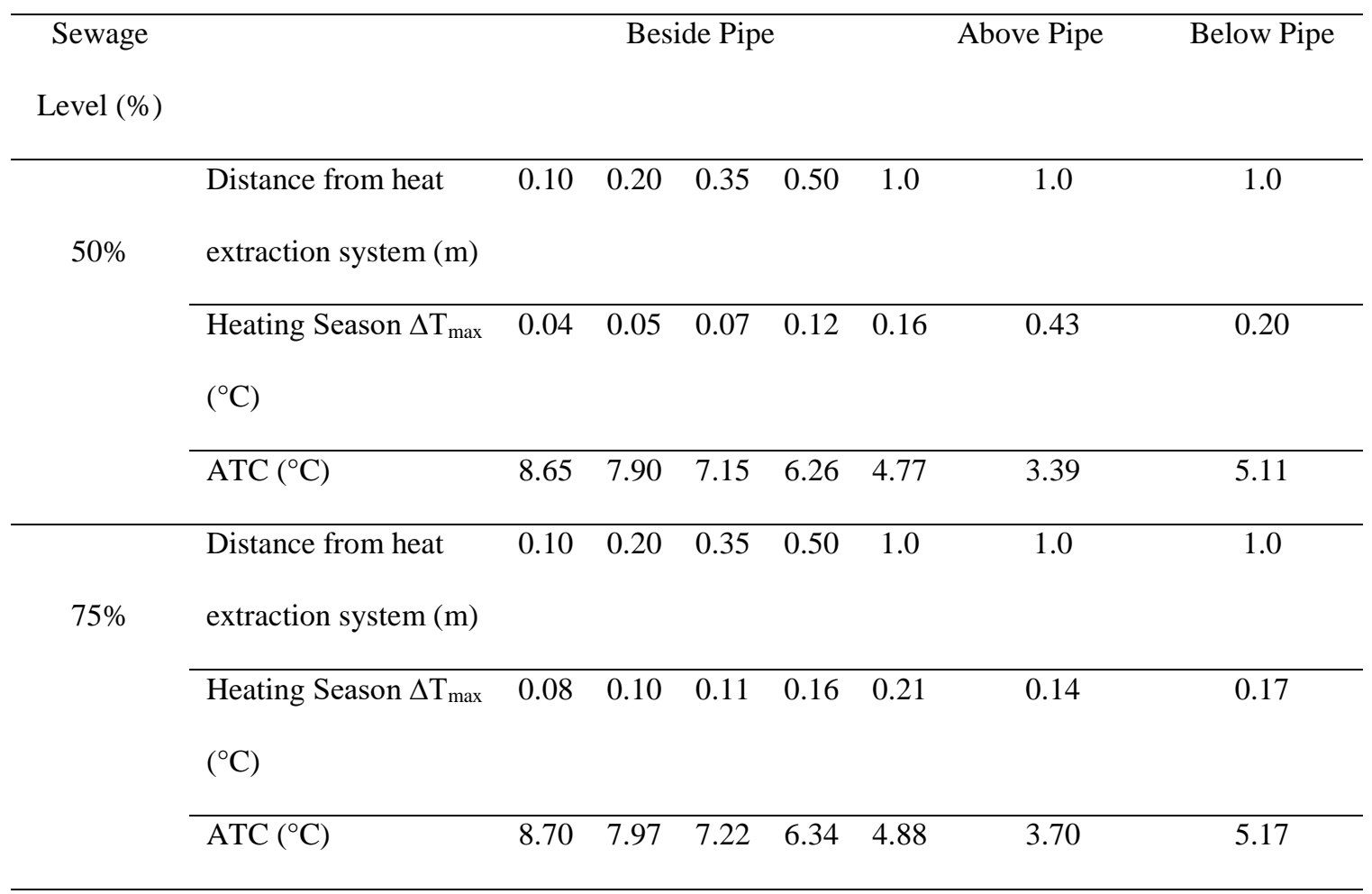




\subsubsection{Theoretical $\mathrm{CO}_{2}$ emission and cost savings}

Table 8 shows the additional work required from the heat pump in order to meet the energy demand of a typical Canadian Prairie home (Table 1) from the average monthly energy entering the heat pump system during the heating and cooling seasons, which was calculated at $15.7 \mathrm{~W}_{\text {in }} \mathrm{kWh}$ and $60.4 \mathrm{~W}_{\text {in }} \mathrm{kWh}$ respectively. The monthly additional work required is denoted as $\mathrm{W}_{\text {in }}$ in $\mathrm{kWh}$ and the COP's are represented by the coefficients during the corresponding season. The calculations were based on the temperature difference between a constant inlet temperature function and simulated outlet temperatures from the heat exchanger by using Eq. 1. The required monthly work input (Table 8) was also calculated by using Eq. 1.

Table 8: Required monthly work input for heat pump to meet energy demand.

\begin{tabular}{lc}
\hline Month & Work input (kWh) \\
\hline January & 28.9 \\
\hline February & 28.7 \\
\hline March & 16.6 \\
\hline April & 17.3 \\
\hline May & 21.1 \\
\hline June & 27.6 \\
\hline July & 25.4 \\
\hline August & 27.3 \\
\hline September & 23.1 \\
\hline October & 14.4 \\
\hline November & 18.4 \\
\hline
\end{tabular}




\begin{tabular}{lc}
\hline December & 20.5 \\
\hline Total & 269.5
\end{tabular}

The net present value for the power consumption cost over a 25 -year operating period is necessary to determine the lifetime system savings and was calculated by using the following equation:

$$
P=\frac{C}{1+g} \frac{(1+x)^{n}-1}{x(1+x)^{n}}
$$

where $\mathrm{P}$ is the net present value, $\mathrm{C}$ is the power consumption cost in the first year [CAD\$], $\mathrm{n}$ is the project lifetime taken as 25 years, $\mathrm{g}$ is the average inflation rate in Canada from 1993-2018 taken as 1.79\% (The World Bank Online Data Center, 2019) and $\mathrm{x}$ is the relationship factor calculated from the following:

$$
x=\frac{1+i}{1+g}-1
$$

where $\mathrm{i}$ is the average interest rate in Canada from 1992-2017 taken as 4.82\% (The World Bank Online Data Center, 2019).

Based on the calculations from Eq. 12 and 13, the net present value of the power consumption cost for a 25 -year operating period is 17.15 times the cost compared to the first year of operation. The first year operating costs for the @ Source-Energy pipe system (Table 8), the heat exchanger circulating pump, and a typical Canadian Prairie residential heating and cooling system (Table 1) were derived from the Manitoba cost of electricity of $8.196 \notin / \mathrm{kWh}$ and the Manitoba cost of natural gas of $7.62 \notin / \mathrm{m}^{3}$ (Manitoba Hydro, 2019a). The operating costs and savings over the 25 -year period were then calculated as seen in Table 9 using the conversion factor for net present value and Eq. 12. 
Table 9: Annual operating costs and savings for a 25 -year period based on a $10 \mathrm{~m}$ length of pipe.

\begin{tabular}{lcccc}
\hline Description & $\begin{array}{c}\text { Heat exchanger circulat- } \\
\text { ing pump }\end{array}$ & $\begin{array}{c}\text { Heat pump } \\
\text { unit }\end{array}$ & $\begin{array}{c}\mathrm{A} / \mathrm{C} \text { unit and natural } \\
\text { gas furnace }\end{array}$ & $\begin{array}{c}\text { Total operational } \\
\text { savings }\end{array}$ \\
\hline Costs (CAD\$) & 189.25 & 378.80 & 12563.58 & 11995.53
\end{tabular}

In order to determine the lifetime savings of the system, the capital costs for installing the @Source-Energy pipe were summated in Table 10 based on a 10 m system length installed at a $3 \mathrm{~m}$ depth. Table 9 and 10 show the total lifetime profit from installing the @ Source-Energy pipe was CAD $\$ 3345.53$ over a 25-year operating period. Additionally, the $\mathrm{CO}_{2}$ eq. emissions from operating the natural gas furnace and $\mathrm{AC}$ unit system were calculated to be 10.2 tons annually whereas the @Source-Energy pipe system emitted 0.27 tons of $\mathrm{CO}_{2}$ eq. with a total emissions reduction of 248 tons of $\mathrm{CO}_{2}$ eq. for a 25 -year operating period.

Table 10: @ Source-Energy pipe system capital costs for the base case.

\begin{tabular}{lcccc}
\hline Description & Excavation/backfill & Heat pump & Manufacturing and instal- & Total capital \\
& & unit & lation & cost \\
\hline Cost (CAD\$) & 2250.00 & 5000.00 & 1400.00 & 8650.00 \\
\hline
\end{tabular}




\section{Chapter 4 - Conclusion and Recommendation}

\section{for Future Work}

\subsection{Conclusion}

Based on the sustainability target set, the @ Source-Energy pipe can be established as a sustainable option for heat extraction. The change in temperature distribution laterally from the @Source-Energy pipe implementation remained constant at $4 \mathrm{~m}$ adjacent to the pipe. This shows applicability to increase the number of pipes located within one area thus simulating a new residential development. The effect on heat transfer from the HDPE thermal properties included in the heat extraction system was deemed insignificant due to the high correlation coefficient of 0.93 between the datasets with and without the implementation of the thermal properties. Additionally, the system implementation at 4, 5, 6, 7 and 8 m depths showed that thermal balancing was achieved due to the utilization of the sewage heat flux. All analyses maintained a satisfied sustainability target, which shows the ability to implement the system as a typical gravity-assisted sewage system. The increase in sewage pipe capacity from $25 \%$, to $50 \%$ and $75 \%$ showed an $8.7 \%$ and $10.5 \%$ increase in sewage heat flux from the additional sewage while maintaining the sustainability target threshold. Lastly, the system was shown to reduce $\mathrm{CO}_{2}$ emissions and produce profit over the 25-year lifetime operating period. The total profit was $\mathrm{CAD} \$ 3345.53$ and the total $\mathrm{CO}_{2}$ emissions reduced were 248 tons of $\mathrm{CO}_{2}$ eq. This study shows the feasibility of implementing the @Source-Energy pipe in residential homes to replace natural gas furnaces and AC 
units. This would contribute to reducing Canada's GHG emissions and support Canada's target for 2030 GHG emissions as agreed to on the Paris Agreement.

\subsection{Recommendations for future work}

A limitation of this study is the model validation and the comparison between experimental results with simulated results. The continuation study would involve building a prototype of the @Source-Energy pipe system. The prototype would be approximately 30 $\mathrm{m}$ long and be equipped with temperature sensors, flow rate sensors, a heating element, two pumps, and a geothermal unit. The measurements would include the heat fluxes at different sewage temperatures and sewage levels. This would allow for validation of the numerical model and real world results for further validation of the @ Source-energy pipe implementation feasibility.

Another limitation of this study is a constant sewage temperature that directly effects the energy available for the @Source-Energy pipe. In order to analyze the @ Source-Energy pipe with increased accuracy, the system with an increased amount of users must be evaluated. With a large amount of users attached to one system, the temperature difference within the soil and effluent compared with the refrigerant will decrease over time. For this continuation study, the sewage temperature will be a function of the heat extraction rate with an initial temperature of $15^{\circ} \mathrm{C}$. This will allow for the analysis of the temperature differential down flow in the sewage line as an increasingly amount of houses are extracting heat. This approach will allow extrapolating results and sizing the @ Source-Energy Pipe system to the community level. Based on the energy consumption, 
more and more houses in a community area will be added to the heat transport model to investigate the thermal impacts on the sewage and soil temperature at a large scale.

Due to the complexity of the $10 \mathrm{~m}$ model investigated in this thesis, a daily time-step was used in order to analyze the system long-term. The increase in scale from a $10 \mathrm{~m} \mathrm{sec-}$ tion to a city quarter will cause numerical instability due to the complex and large-scale model. Due to this, the simplification of the model is necessary. The approach used to simplify the model will be to remove the helix where the heat exchange fluid circulates and replace it with a cylinder. A 7-day sensitivity analysis will be performed in order to investigate the difference in heat transfer performance between the two geometries. The change in geometry will allow for a daily time-step due to the reduced nodes from the simplified mesh. 


\section{Bibliography}

Ajah, A. N., Mesbah, A., Grievink, J., Herder, P. M., Falcao, P. W., \& Wennekes, S. 2008. On the robustness effectiveness and reliability of chemical and mechanical heat pumps for low-temperature heat source district heating : A comparative simulation-based analysis and evaluation. 33: 908-929.

Alnahhal, S., \& Spremberg, E. 2016. Contribution to Exemplary In-House Wastewater Heat Recovery in Berlin,, 13th Global Conference on Sustainable Manufacturing, Vol. 40: 35-40. Ho Chi Minh: Elsevier B.V.

Baek, N. C. 2005. A study on the design and analysis of a heat pump heating system using wastewater as a heat source. Solar Energy, 78: 427-440.

Bergman, T. L., Lavine, A. S., Incropera, F. P., \& Dewitt, D. P. 2007. Fundamentals of Heat and Mass Transfer (7th ed.). Hoboken: John Wiley \& Sons, Inc.

Betcher, R., Grove, G., \& Pupp, C. 1995. Groundwater in Manitoba: Hydrogeology, Quality Concerns, Management: 1-4: Environment Canada.

Bi, Y., Chen, L., \& Wu, C. 2002. Ground heat exchanger temperature distribution analysis and experimental verification. Applied Thermal Engineering, 22: 183-189.

Bose, J. E., Smith, M.D., Spitler, J.D. 2002. Advances in Ground Source Heat Pump Systems - An international Overview. Proceedings of the Seventh International Energy Agency Heat Pump Conference: 313-324.

Callendar, H. L. 1911. The Caloric Theory of Heat and Carnots Principle. Paper presented at the Proceedings of the Physical Society of London, London, England.

Chen, J., Ma, C., Ji, X., Lu, X., \& Wang, C. 2017. Mechanism Study of Waste Heat Recovery from Slurry by Surface Scraped Heat Exchanger. Energy Procedia, 105: 1109-1115.

City of Winnipeg. 2017. Cold Weather Impact Archive. In C. o. Winnipeg (Ed.): 1-1. Winnipeg: Water and Waste Department.

City of Winnipeg. 2018. City provides update on frozen water pipes, News Releases: 1-1. Winnipeg: City of Winnipeg.

City of Winnipeg. 2019. South End Sewage Treatment Plant Inlet Sewage Tempeatures. Winnipeg.

COMSOL Multiphysics. 2007. COMSOL Multiphysics, 5.4a ed.: 574. Burlington.

COMSOL Multiphysics. 2017. How to Inspect Your Mesh in COMSOL Mutiphysics. In C. Multiphysics (Ed.), Vol. 2020.

Culha, O., Gunerhan, H., Biyik, E., Ekren, O., \& Hepbasli, A. 2015. Heat exchanger applications in wastewater source heat pumps for buildings : A key review. Energy \& Buildings, 104: 215-232.

Dai, L. H., Shang, Y., Li, X. L., \& Li, S. F. 2016. Analysis on the transient heat transfer process inside and outside the borehole for a vertical U-tube ground heat exchanger under short-term heat storage. Renewable Energy, 87: 1121-1129.

Dölçek, A. Ö., Atkins, I., Harper, M. K., Tinjum, J. M., \& Choi, C. Y. 2017. Performance and Sustainability of District-Scale Ground Coupled Heat Pump Systems. Geotechnical and Geological Engineering: 843-856.

Elżbieta, N. 2018. The residential heat pumps 'impact on national $\mathrm{CO}_{2}$ emission. 00123.

Farshad, F., Rieke, H., \& James, G. 2001. New developments in surface roughness measurements, characterization, and modeling fluid flow in pipe. Journal of Petroleum Science and Engineering(29): 139-150.

Ferguson, G., \& Woodbury, A. D. 2004. Subsurface heat flow in an urban environment. Journal of Geophysical Research, 109: 1-9. 
Frijns, J., Hofman, J., \& Nederlof, M. 2013. The potential of wastewater as energy carrier. Energy Conversion and Management, 65: 357-363.

Fujii, H., Tsuya, S., Harada, R., \& Kosukegawa, H. 2019. Field test of horizontal ground heat exchangers installed using horizontal directional drilling technology. In S. University (Ed.), 44th Workshop on Geothermal Reservoir Engineering. Stanford, California: Stanford University.

Garcia, R., Verhoef, A., Luigi, P., Main, B., \& Gan, G. 2012. Interactions between the physical soil environment and a horizontal ground coupled heat pump, for a domestic site in the UK. Renewable Energy, 44: 141-153.

Gauthier, C., Lacroix, M., \& Bernier, H. 1997. Numerical simulation of soil heat exchangerstorage systems for greenhouses. Solar Energy, 60(6): 333-346.

Government of Canada. 2015. Canada's Second Biennial Report on Climate Change, Ottawa.

Government of Canada. 2019. Environment Canada 2018. In E. Canada (Ed.).

Hafeez, A., \& Abdalla, M. 1972. Thermal conductivity of polyethylene pipes embedded in concrete. Iowa State University, Ames, Iowa.

Hein, P., Kolditz, O., Görke, U.-J., Bucher, A., \& Shao, H. 2016. A numerical study on the sustainability and efficiency of borehole heat exchanger coupled ground source heat pump systems. Applied Thermal Engineering, 100: 421-433.

Jessop, A. M., \& Judge, A. S. 1971. Five measurements of heat flow in southern Canada. Canadian Journal of Earth Sciences, 8: 711-716.

Kayaci, N., \& Demir, H. 2018. Geothermics Numerical modelling of transient soil temperature distribution for horizontal ground heat exchanger of ground source heat pump. Geothermics, 73: 33-47.

Kjartanson, B. 1983. Geological Engineering Report for Urban Development of Winnipeg. Winnipeg, Manitoba: Department of Geological Engineering.

Liu, H., Maghoul, P., \& Holländer, H. M. 2019. Sensitivity analysis and optimum design of a hydronic snow melting system during snowfall. Physics and Chemistry of the Earth: 0-1.

Lund, J. W., Freeston, D. H., \& Boyd, T. L. 2010. Direct Utilization of Geothermal Energy 2010 Worldwide Review. Paper presented at the World Geothermal Congress 2010, Bali, Indonesia.

Manitoba Hydro. 2009. Performance of Ground Source Heat Pumps in Manitoba. In Manitoba Hydro (Ed.): 73. Winnipeg, Manitoba.

Manitoba Hydro. 2019a. Manitoba Hydro Electricity Rate.

Manitoba Hydro. 2019b. MyBill: Manitoba Hydro.

Meggers, F., \& Leibundgut, H. 2011. The potential of wastewater heat and exergy : Decentralized high-temperature recovery with a heat pump. Energy \& Buildings, 43: 879-886.

Melinder, A. 2007. Thermophysical Properties of Aqueous Solutions Used as Secondary Working Fluids. Royal Institute of Technology, Stockholm, Sweden.

Michopoulos, F., \& Kyriakis, N. 2009. Predicting the fluid temperature at the exit of the vertical ground heat exchangers. 86: 2065-2070.

Mihelcic, J. R., \& Zimmerman, J. B. 2014. Environmental Engineering (Second ed.). Danvers: John Wiley \& Sons, Inc.

National Energy Board. 2017. Canada's Energy Future 2017. In D. o. Energy (Ed.). Ottawa.

Natural Resources Canada. 2013a. Energy Efficiency Trends in Canada 1990-2013. In N. R. Canada (Ed.). Ottawa: Government of Canada.

Natural Resources Canada. 2013b. Survey of Household Energy Use 2011. In N. R. Canada (Ed.). Ottawa: Government of Canada.

Neuberger, P., Adamovský, R., \& Šedová, M. 2014. Temperatures and heat flows in a soil enclosing a slinky horizontal heat exchanger. Energies, 7: 972-987. 
Neupauer, K., Pater, S., \& Kupiec, K. 2018. Study of Ground Heat Exchangers in the Form of Parallel Horizontal Pipes Embedded in the Ground. Energies, 11: 491.

Peráčková, J., \& Podobeková, V. 2013. Utilization of heat from sewage. Budownictwo o zoptymalizowanym potencjale energetycznym, 2: 79-86.

Renewable Resource Recovery Corp. 2009.@Source-Energy Pipe.

Saaly, M., Maghoul, P., Kavgic, M., \& Polyzois, D. 2019. Performance analysis of a proposed geothermal pile system for heating and cooling energy demand for a building in cold regions. Sustainable Cities and Society, 45: 669-682.

Shin, J. H., \& Cho, Y. H. 2018. Development of a variable water flow rate control method for the circulation pump in a geothermal heat pump system. Energies, 11.

The World Bank Online Data Center. 2019. The World Bank Online Data Center, Vol. 2019.

U.S. Department of Energy. 2011. Guide to Geothermal Heat Pumps. In U.S. Department of Energy (Ed.): 1-2: United States Government.

United States Environmental Protection Agency. 2017. Greenhouse Gases Equivalencies Calculator - Calculations and References, Vol. 2019.

Verlag des Vereins Deutscher Ingenieure. 2001. VDI 4640-2: 6. Düsseldorf: Verlag des Vereins Deutscher Ingenieure.

Wang, J., Long, E., \& Qin, W. 2013. Numerical simulation of ground heat exchangers based on dynamic thermal boundary conditions in solid zone. Applied Thermal Engineering, 59: 106-115.

Welty, J., Rorrer, G. L., \& Foster, D. G. 2014. Fundamentals of momentum, heat and mass transfer. New York Wiley Global Education.

Zhu, M., \& Michalowski, R. L. 2005. Simulation of Heat Transfer in Freezing Soils Using ABAQUS. In A. Arbor (Ed.), Abaqus Users' Conference: 1-7. University of Michigan. 